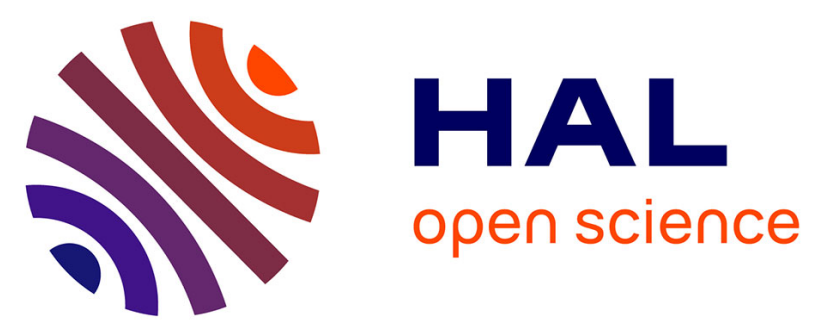

\title{
Sedimentary record of environmental changes and human interferences in a macrotidal bay for the last millenaries: the Marennes-Oleron Bay (SW France)
}

Jonathan Allard, Eric Chaumillon, Xavier Bertin, Clément Poirier, Florian Ganthy

\section{To cite this version:}

Jonathan Allard, Eric Chaumillon, Xavier Bertin, Clément Poirier, Florian Ganthy. Sedimentary record of environmental changes and human interferences in a macrotidal bay for the last millenaries: the Marennes-Oleron Bay (SW France). Bulletin de la Société Géologique de France, 2010, 2, 10.2113/gssgfbull.181.2.151 . hal-01242285

\section{HAL Id: hal-01242285 \\ https://hal.science/hal-01242285}

Submitted on 11 Dec 2015

HAL is a multi-disciplinary open access archive for the deposit and dissemination of scientific research documents, whether they are published or not. The documents may come from teaching and research institutions in France or abroad, or from public or private research centers.
L'archive ouverte pluridisciplinaire HAL, est destinée au dépôt et à la diffusion de documents scientifiques de niveau recherche, publiés ou non, émanant des établissements d'enseignement et de recherche français ou étrangers, des laboratoires publics ou privés. 


\title{
Sedimentary record of environmental changes and human interferences in a macrotidal bay for the last millenaries: the Marennes-Oléron Bay (SW France)
}

\author{
JONATHAN ALLARD ${ }^{1}$, ERIC CHAUMILLON ${ }^{1}$, XAVIER BERTIN ${ }^{1}$, CLÉMENT POIRIER ${ }^{1}$ and FloRian GANTHY ${ }^{1}$
}

\begin{abstract}
Key-words. - Estuary, Tidal channel, Mud drape, Holocene, Sea level rise, Bedrock control, Tides, Human impact, Bathymetry, Very high resolution seismic.

Abstract. - This synthesis of the morphological and stratigraphical evolutions of the Marennes-Oléron Bay (west coast of France) combines bathymetric data (1824 and 2003) and very high-resolution seismic profiling groundtruthed by vibracore samples. The Marennes-Oléron Bay is characterised by a very high sedimentation rate and appears to be an ideal place to investigate the sedimentary record of the major environmental changes that occurred since the last several millennia.

The sediment budget of the Marennes-Oléron Bay, between 1824 and 2003, is clearly positive. The flood-dominated northern Marennes-Oléron Bay displays sediment gain in both intertidal and subtidal areas whereas the ebb-dominated southern Marennes-Oléron Bay displays sediment gain restricted to the intertidal area and deepening of subtidal channels. In addition, human influences such as oyster farming may play a role in the sediment gain of the bay.

The sediment-fill of the northern Marennes-Oléron Bay consists of five main phases: (1) lenticular units and flooded intertidal flats recording lower sea level periods before $7500 \mathrm{yr}$ B.P.; (2) tidal channel-fills recording changes in tidal drainage pattern from 7500 to 5000 yr B.P.; (3) a subtidal unit which constitutes the main phase of sediment fill in the northern part of the bay from 5000 to $1500 \mathrm{yr}$ B.P.; (4) a major channelized erosional surface related to huge coastline changes from 1500 to 1000 yr B.P.; and (5) a mud drape emplaced during the last millennia and potentially recording historical human impact (deforestation and land reclamation). The sediment fill of the southern Marennes-Oléron consists of sandbanks, mixed sand-and-mud flats and tidal channels, mainly emplaced under wave-and-tide processes since the last centuries.

Despite its relatively thin (20 $\mathrm{m}$ at the maximum), recent and rapid sediment fill, the stratigraphic organization and morphological evolution of the Marennes-Oléron Bay is very complex and spatially variable. Like in many other estuaries, sediment fill of the Marennes-Oléron Bay was successively controlled by relative sea level changes, and then by sediment supply driven by hydrodynamic changes related to huge coastline migrations, and finally by human activities. Moreover, this kind of "rocky coast" estuary, where the sediment-fill is very thin and discontinuous, is characterised by a bedrock control at each phases of the sediment fill both in terms of preservation in topographic lows and in terms of control on hydrodynamics and related sediment input.
\end{abstract}

\section{Enregistrement sédimentaire des changements environnementaux et des interférences humaines dans une baie macrotidale au cours des derniers millénaires : la baie de Marennes-Oléron (SW France)}

\begin{abstract}
Mots-clés. - Estuaire, Chenal de marée, Drapage vaseux, Holocène, Remonté du niveau de la mer, Contrôle par le socle rocheux, Marée, Activité anthropique, Bathymétrie, Sismique très haute résolution.

Résumé. - Cette synthèse sur les évolutions morphologiques et stratigraphiques de la baie de Marennes-Oléron (côte ouest de la France) repose sur des données bathymétriques (1824 et 2003), des enregistrements sismiques à très haute résolution et des carottages. La baie de Marennes-Oléron qui se caractérise par de très forts taux de sédimentation représente un site idéal pour étudier l'enregistrement sédimentaire des changements environnementaux qui se sont produits lors des derniers millénaires.

Le budget sédimentaire de la baie de Marennes-Oléron, entre 1824 et 2003 est clairement positif. Dans la partie nord de la baie, dominée par le flot, le gain sédimentaire se situe à la fois dans les zones inter-et subtidales, alors que dans la partie sud de la baie, dominée par le jusant, le gain sédimentaire se limite aux zones intertidales avec un creusement des chenaux subtidaux. L'activité ostréicole semble jouer un rôle dans le gain sédimentaire au niveau des zones intertidales.

Le comblement sédimentaire de la partie nord de la baie de Marennes-Oléron comprend cinq phases principales, de la base vers le sommet: (1) des unités lenticulaires et des estrans enregistrant des périodes de plus bas niveau marin avant 7500 B.P. ; (2) des comblements de chenaux témoignant de réorientations dans le drainage de la baie entre 7500 et 5500 B.P. ; (3) une unité subtidale mise en place entre 5500 et 1500 B.P. et qui constitue la plus grande partie du comblement ; (4) une surface d'érosion majeure liée à une mobilité drastique du trait de côte entre 1500 et 1000 B.P. ; (5) un drapage vaseux déposé depuis le dernier millénaire et enregistrant probablement l'impact anthropique de la déforestation et de la poldérisation. Dans la partie sud de la baie de Marennes-Oléron des bancs de sable, des estrans mixtes
\end{abstract}

1. University of La Rochelle, UMR LIENSS 6250, Institut du Littoral et de l'Environnement, 2 rue Olympe de Gouges, 17000 La Rochelle cedex, France, tel : 33 (0) 546457231 ; fax : 33 (0) 546458274 . eric.chaumillon@ univ-lr.fr

Manuscrit déposé le 15 octobre 2008 ; accepté après révision le 15 janvier 2009. 
sablo-vaseux et des chenaux tidaux constituent un comblement rapide depuis les derniers siècles principalement. L'ensemble des données montre que malgré un comblement sédimentaire peu épais (20 m au maximum), récent et rapide, les évolutions morphologiques et l'organisation stratigraphique de la baie de Marennes-Oléron sont très complexes et variables dans l'espace. Comme dans la plupart des estuaires, le comblement sédimentaire de cette baie a successivement été contrôlé par les changements relatifs du niveau de la mer, puis par les apports sédimentaires gouvernés par des changements hydrodynamiques en relation avec des migrations importantes du trait de côte et enfin par les activités humaines. Une originalité de ce type d'estuaire de côte rocheuse, caractérisé par une couverture sédimentaire très fine et discontinue, est le contrôle par la morphologie du socle rocheux à toutes les étapes du comblement, tant du point de vue de la préservation des sédiments dans les creux topographiques, que du point de vue de la modification des paramètres hydrodynamiques et des apports sédimentaires qui leurs sont associés.

\section{INTRODUCTION}

Present-day estuaries are natural sediment sinks and are rapidly filled with sediments at both geological (millennia) and historical time scale (decades to centuries). The main processes governing their sediment-fill include [Zaitlin et al., 1994] relative sea level rise, hydrodynamics (waves and tidal currents), bedrock shape and sediment supply (marine and continental). Previously, studies reported that modern estuarine environments in Europe allow the distinction of four main phases of sediment infilling. From 10000 to 6500 years B.P. (phase 1), rapid relative sea level rise (about $7 \mathrm{~mm} . \mathrm{yr}^{-1}$ ) [Lambeck, 1997] was the main parameter controlling sedimentation [Dias et al., 2000; Long et al., 2000; Freitas et al., 2002]. During this first period, sedimentation rate was high and reached few millimeters per year [Dabrio et al., 2000; Dias et al., 2000; Boski et al., 2002; Lario et al., 2002]. From 6000 to 3000 years B.P. (phase 2), deposition of extensive peat levels [Devoy, 1979; Delanay and Devoy, 1995; Regnauld et al., 1996; Spencer et al., 1998; Waller et al., 1999; Allen, 2000a and b; Clavé et al., 2001], development of barrier islands and sand spits and closure of estuaries [Boski et al., 2002; Freitas et al., 2002] have been related to a relative sea level stillstand. From 3000 to 2000 years B.P. (phase 3), deposition of marine sediments occurred during an episode of renewed sea level rise [Mary et al., 1975; Visset, 1988; Breton et al., 1991; Cearetta, 1993; Delanay and Devoy, 1995; Cearetta and Murray, 1996; Regnauld et al., 1996; Sánchez Goñi, 1996; Spencer et al., 1998; Waller et al., 1999; Allen, 2000a]. From 2000 years B.P. to present (phase 4), sedimentation within estuaries was mainly controlled by both climate changes and increasing human activities. Human activities since 2000 years have mainly included extensive land reclamation and deforestation [Pontee et al., 1998; Pawlowski, 1998]. The former leads to a decrease of tidal prism and an increase of sedimentation following a positive feedback loop mechanism [Van der Wal et al., 2002; Bertin et al., 2005]. The latter leads to soil erosion and an increase of sedimentation [Pitte, 1983; Higounet, 1985; Dabrio et al., 2000]. Hence it appears that sedimentation of modern European estuaries was initially controlled by the early Holocene rapid sea-level rise and later by the complex interactions between human activities, climate, sediment supply and long-term morphodynamic behaviour.

Characterised by a very high sedimentation rate [Gouleau et al., 2000; Bertin et al., 2005], the Marennes-Oléron bay (MOB, figs $1 \mathrm{~b}$ and c) appears to be an ideal place to investigate the sedimentary record of the major environmental changes that occurred since the last several millenia [Chaumillon et al., 2004; Billeaud et al., 2005], in order to help us understand the relative importance of the various parameters controlling estuarine infilling. In this study, the sedimentary record of the MOB is investigated using a dense grid of new very high-resolution seismic data combined with historical bathymetric data and core analysis.

\section{SETTING AND PREVIOUS WORK IN THE STUDIED AREA}

\section{General setting}

The MOB is located in the Bay of Biscay about $20 \mathrm{~km}$ to the north of the Gironde estuary (fig. 1a). The MOB is a $190 \mathrm{~km}^{2}$ wide semi-enclosed environment connected to the Atlantic Ocean through the Pertuis d'Antioche to the North, and the Maumusson Inlet to the South (figs 1 and 2). It is bounded seaward by Oléron Island and mainland whose NW-SE elongated rocky outcrops are fringed by extensive marshes (fig. 2). Intertidal flats represent about $60 \%$ of the total surface area of the bay and are cut by sandy tidal channels (fig. 2b). The Marennes-Oléron Bay can be subdivided into four geomorphologic domains: (1) the Longe de Boyard, a $8 \mathrm{~km}$ long elongated sandbank located between two tidal channels in the northern entrance [Chaumillon et al., 2002, 2008a; Bertin and Chaumillon, 2005a], (2) the northern MOB (NMOB, fig. 2b) with the "Rade des Trousses Channel" [Bertin et al., 2005; Bertin and Chaumillon, 2005a] that is bounded to the south by the "Coureau d'Oléron Strait" (COS, fig. 2b), (3) the southern MOB (SMOB, fig. 2b) consisting of mixed sand-and-mud flats cut by tidal channels, and (4) the southern "Maumusson" tidal inlet [Bertin et al., 2004, 2005].

\section{Hydrodynamic setting}

Tides affecting the study area are semi diurnal. MOB is a macrotidal coastal environment with tidal ranges ranging from less than $2 \mathrm{~m}$ during neap tides to more than $6 \mathrm{~m}$ during spring tides. Tides and the associated tidal currents are the dominant forcing in the sedimentary dynamic of MOB, which has already been investigated using numerical models. Tidal currents control the transport and redistribution of sediments, resulting in a flood-dominated residual sand flux within both the northern entrance and Rade des Trousses channel [Bertin, 2005], an ebb-dominated residual sand flux in the southern Maumusson Inlet [Bertin, 2005], and a pronounced onshore residual flux on the eastern mud flat of the Marennes-Oléron Bay [Bassoulet et al., 2000]. 


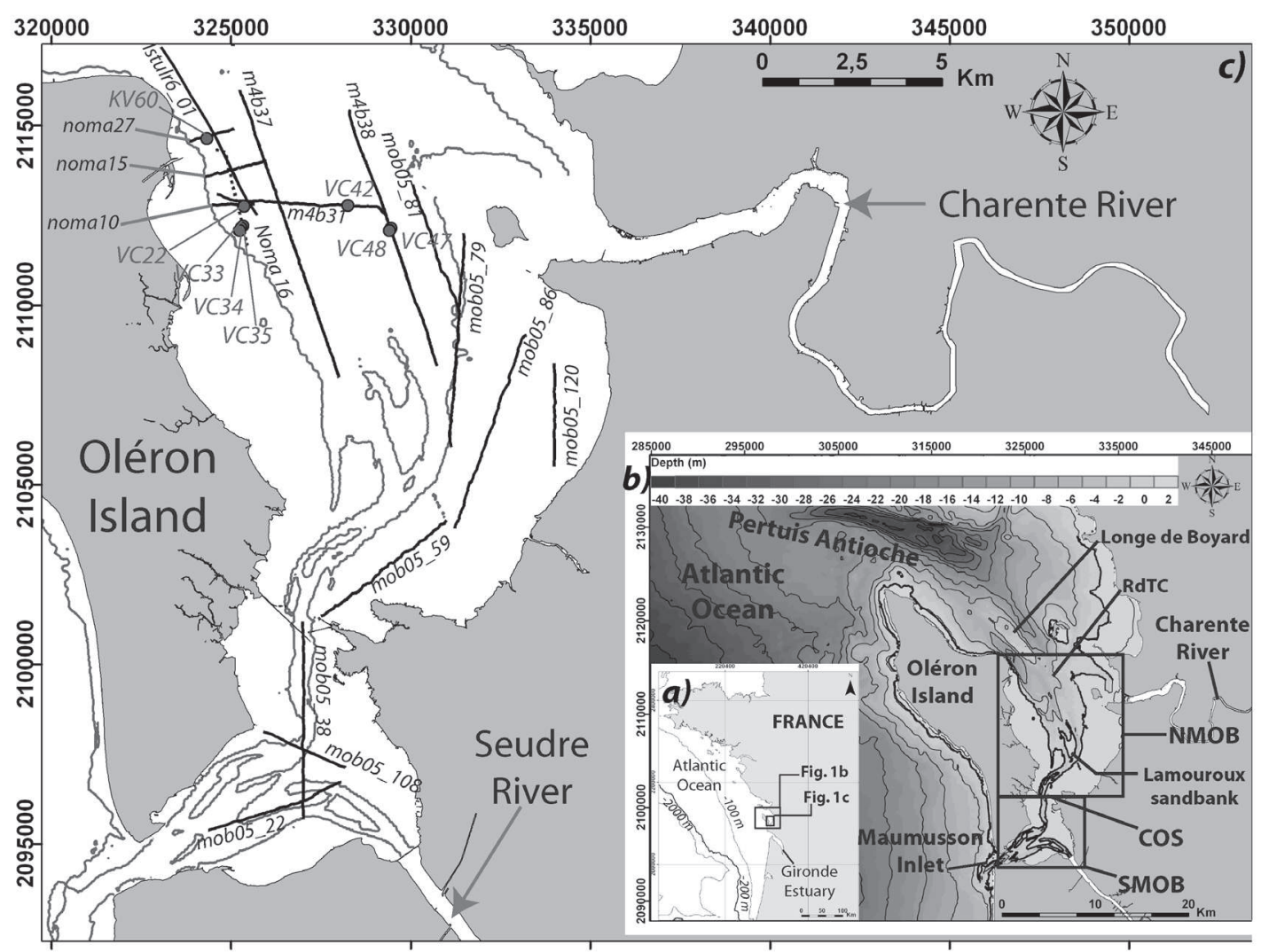

FIG. 1. - Location maps of the study area (NTF geodetic system, Lambert IIe, coordinates in meters). The $0 \mathrm{~m}$ isobath line is in reference to the marine chart-sounding datum at La Rochelle Harbor, that is -3.504 with reference to the Nivellement General de France. (a) Location of the Marennes-Oléron Bay on the West Coast of France. (b) Bathymetric map of the study area with a bathymetric contour of 5 m. NMOB and SMOB represent the northern and the southern Marennes-Oléron Bay, respectively. The Rade des Trousses Channel (RdTC) and the Coureau d'Oléron Strait (COS) are also indicated. (c) Simplified bathymetric map of the Marennes-Oléron Bay, showing the VHR seismic tracks used in this study (bold lines). Circles indicate the location of the vibracores discussed in this study. Seismic profile Noma 16 discussed in Chaumillon et al. [2004] is indicated with a bold dashed line.

FIG. 1. - Cartes de localisation de la zone d'étude (système géodésique NTF, Lambert IIe, coordonnées en m). La courbe isobathe du 0 correspond au niveau de référence hydrographique au port de La Rochelle, soit-3.504 m par rapport au 0 du Nivellement Général de France. (a) Localisation de la baie de Marennes-Oléron (MOB) sur la côte ouest de la France. (b) Carte bathymétrique de la zone d'étude avec un intervalle bathymétrique de 5 m. NMOB correspond à la partie nord de la baie de Marennes-Oléron et SMOB correspond à la partie sud de la baie de Marennes-Oléron. Le chenal de la Rade des Trousses (RdTC) et le Coureau d'Oléron (COS) sont également indiqués. (c) Carte bathymétrique simplifiée montrant les routes sismiques utilisées dans cette étude (traits gras). Les cercles indiquent la position des carottes utilisées dans cette étude. Le profil sismique Noma16 discuté dans Chaumillon et al. [2004] est représenté en trait pointillé gras.

Mean annual significant offshore wave height is about $1.5 \mathrm{~m}$, but winter storms can episodically produce waves larger than $9 \mathrm{~m}$ [Bertin et al., 2008]. Peak wave periods ranging from 8 to 12 s represent more than $60 \%$ of the annual wave climate while periods larger than $15 \mathrm{~s}$ occur more than $2 \%$ of the time. Wave directions are predominantly $\mathrm{W}$ to NW, which represent more than $60 \%$ of the annual wave climate and induce a southward net littoral drift along the southwestern coast of Oléron island [Bertin et al., 2008]. Within the MOB, swells are strongly attenuated but their strong obliquity with respect to the shoreline induces a significant longshore transport, which results in the building of up to hectometer to kilometer long sand spits close to the two entrances of the bay [Bertin et al., 2005]. Wind waves induce mud resuspension during the high-water slack period [Bassoulet et al., 2000].

Two small rivers flow into the MOB, the Charente and the Seudre rivers (fig. $1 \mathrm{~b}$ and c). The volumes of freshwater introduced by these rivers are respectively 65 and $0.55 \mathrm{~m}^{3} . \mathrm{s}^{-1}$ [Tesson, 1973; Bry and Hoflack, 2004], which is more than two orders of magnitude less than those moved by the tide during each tidal cycle [Tesson, 1973; Bertin et al., 2005]. The mean annual solid discharge of the Charente River is about 41000 t [Gonzalez et al., 1991]. Sediment discharge from the Seudre River was not measured but it is likely much lower than those of the Charente River.

\section{Morphological evolution of the Marennes-Oléron Bay}

A synthesis of historical data and maps [Pawlowski, 1998] was used by Bertin [2005] to show the qualitative evolution of the Marennes-Oléron Bay area (fig. 3). This synthesis allowed showing huge changes of the coastline since the last centuries and evidenced the communication between MOB and the Gironde estuary during the Middle Age (fig. 3). Comparison of bathymetric maps produced in 1824 and 1995 has allowed computation of the sediment budget of the MOB [Bertin et al., 2005]. Calculated sediment budget is clearly positive $\left(106 \times 10^{6} \mathrm{~m}^{3}\right.$ added over the last 171 
years). Sediment accretion occurred mainly in four types of areas: (1) close to the connections with the open ocean; (2) in the lower parts of intertidal flats; (3) in the Rade des
Trousses Channel; and (4) in areas where land reclamation has occurred. Sediment erosion occurred mainly within channels of the southern part of the bay. The recent and
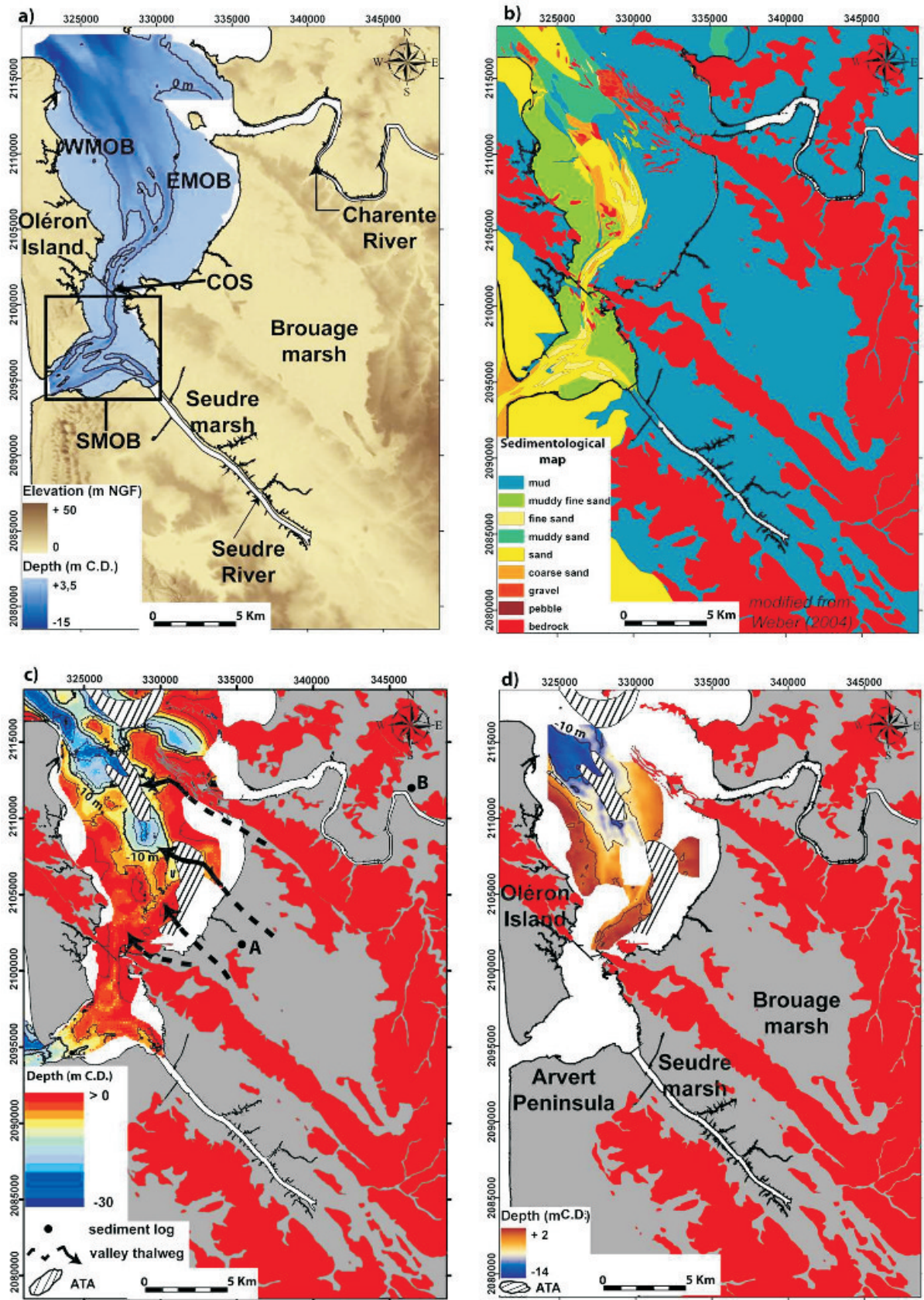

FIG. 2. - (a) Bathymetric (in reference to the marine chart-sounding datum at La Rochelle Harbor) and topographic (in reference to the Nivellement General de France) map of the Marennes-Oléron Bay and surrounding areas. WMOB, EMOB, SMOB and COS represent the western, the eastern, the southern Marennes-Oléron Bay, and the Coureau d'Oléron Strait, respectively. (b) Simplified sedimentological map of the Marennes-Oléron Bay and surrounding areas [modified from Weber, 2004]. (c) Bedrock isobath map of the Marennes-Oléron Bay and location of the continental bedrock outcrops within surrounding areas (in red colour). The Acoustic Turbidity Area (ATA) is indicated by the hachured polygons. $-10 \mathrm{~m}$ bedrock isobath is indicated in bold. Black arrows indicate the location of the thalweg of bedrock incised valley of the EMOB. Circles and letters A and B indicate the location of sediment log already described in Gabet [1969] and Carbonel et al. [1998] respectively. (d) Isobath map of the erosional unconformity EU1 observed within the northern MOB. The Acoustic Turbidity Area (ATA) is indicated with hachured polygons.

FIG. 2. - (a) Carte bathymétrique (niveau de référence : O hydrographique) et topographique (niveau de référence : 0 du Nivellement générale de France) de la baie de Marennes-Oléron et régions adjacentes. WMOB, EMOB, SMOB correspondent aux parties ouest, est, sud et de la baie de Marennes-Oléron et COS indique le Coureau d'Oléron. (b) Carte sédimentologique simplifiée de la baie de Marennes-Oléron et régions adjacentes [d'après Weber, 2004]. (c) Carte isobathe du socle rocheux et localisation des affleurements rocheux (en rouge). La zone de turbidité acoustique est représentée en hachuré. La courbe isobathe du socle rocheux à $-10 \mathrm{~m}$ est indiquée en gras. Les flèches indiquent les thalwegs des vallées dans la partie orientale de la baie de Marennes-Oléron. Les cercles et lettres A et B indiquent la position des carottes respectivement décrites dans Gabet [1969] and Carbonel et al. [1998]. (d) Carte isobathe de la discordance érosionnelle EU1 identifiée dans la partie nord de la baie de Marennes-Oléron. La zone de turbidité acoustique est représentée en hachuré. 

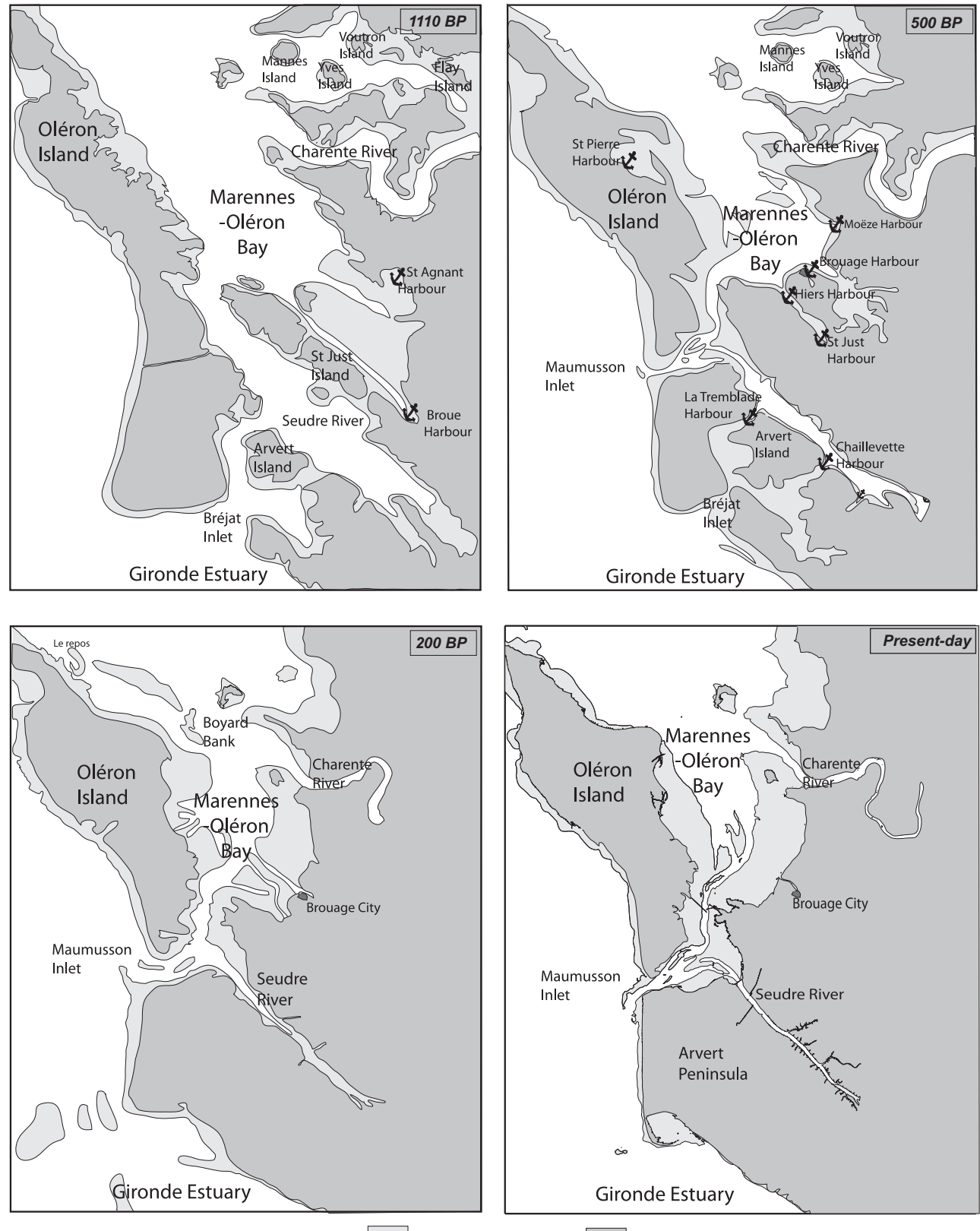

« Ancient Harbour

Intertidal areas

emerged land

FIG. 3. - Historical evolution of the coastline in the vicinity of the Marennes-Oléron Bay [modified from Bertin, 2005].

FIG. 3. - Evolution historique du trait de côte dans la région de la baie de Marennes-Oléron [modifié d'après Bertin, 2005$].$

rapid sediment infilling of the bay has been attributed to both natural processes and human activities [Bertin et al., 2005; Bertin and Chaumillon, 2006].

\section{Stratigraphy of the Marennes-Oléron Bay}

Previously published seismic profiles were obtained for the northern entrance of the bay [Chaumillon et al., 2002, 2008a], at Maumusson Inlet [Bertin et al., 2004] and in the Rade des Trousses Channel [Chaumillon et al., 2004; Billeaud et al., 2005; Bertin and Chaumillon, 2006]. Within the Rade des Trousses Channel, those previous workers have identified four main seismic units and three of them were cored. The uppermost unit is a mud drape that can be related to three concomitant main causes: (1) natural infilling process that leads to a decrease in the tidal prism and, in turn, to positive feedback and an increase in sedimentation [Pendon et al., 1998; van der Wal et al., 2002]; (2) climate changes resulting in an increase in suspended matter input [Bourrin et al., 2007]; (3) human activities, including land reclamation and deforestation leading to the expulsion of suspended-matter which induced the increased sedimentation and deposition of muddier sediments within the estuary.

It is the aim of this study to make a synthesis of both seismic and bathymetric results to understand better the sediment-infilling history of the MOB and the related forcing parameters. 


\section{METHODOLOGY}

\section{Bathymetric data}

A set of historical (1824) and recent (2003) bathymetric data was extracted from the database of the "Service Hydrographic et Océanographique de la Marine" (SHOM) and of the local hydrographic service ("Direction Départementale de l'Equipement", DDE 17), respectively. The historical bathymetric data set was collected using lead line, positioned using horizontal sextant and was georeferenced using ArcView software (ESRI) and extensions developed by the SHOM. The local geodesic system New Triangulation of France (NTF) was chosen, with Clarke 1880 as the reference ellipsoid. Planar Lambert II co-ordinates were calculated for a geomorphological description together with surface and volume computations. The reference level of sounding reduction was defined as the marine chart-sounding datum at La Rochelle Harbour, that is $-3.504 \mathrm{~m}$ with reference to Institut Géographique National 1969 [SHOM, 2003]. Digital elevation models (DEM) were developed using ArcView 9.1 software and the 3-D Analyst extension (ESRI), using a kriging interpolation technique and a grid spacing of $50 \mathrm{~m}$ (fig. 4). Depth errors for the 1824 bathymetric data were checked by assuming stability of rocky outcrops between the two surveys [Bertin et al., 2005] and were estimated to be $\pm 0.35 \mathrm{~m}$ at the maximum. According to SHOM, the relative error does not exceed $+/-10 \mathrm{~m}$ in position and $+/-0.5 \mathrm{~m}$ in depth for 1824 data. According to the DDE 17, the maximum relative error does not exceed $1 \mathrm{~m}$ horizontally and $0.1 \mathrm{~m}$ vertically for the 2003 bathymetric data. The random component included in these errors is significantly reduced for volume and sedimentation-rate estimations due to the fact that these computations utilize a large number (45000 for 2003 data) of sounding points [Thomas et al., 2002]. Consequently, it can be argued that the uncertainties of the values derived from the bathymetric data are significantly overestimated. The secular volume computations were calculated using the difference between the 2003 and the 1824 DEMs. A conservative approach was adopted where only elevation changes greater than $\pm 0.5 \mathrm{~m}$ between subsequent surveys were considered to be significant [Van der Wal et al., 2002; Bertin et al., 2005].

\section{Seismic profiling and stratigraphy}

The stratigraphy was investigated using more than $600 \mathrm{~km}$ of seismic profiles recorded during the number of seismic surveys NOMADE (2000) and MOB05 (2005), on "Les Deux Mouettes" vessel, and MOBIDYC 4 (2004) and LSTULR6 (2006) on CNRS/INSU R/V “Côte d'Aquitaine" (fig. 1c). A boomer plate associated with a line in cone receiver (vertical resolution of $0.25 \mathrm{~m}$ ) [Simpkin and Davis, 1993] was used to image the detailed internal architecture of the MOB. The shot interval was 250 or $500 \mathrm{~ms}$, which corresponds to the average distances between adjacent seismic traces of 0.4 and $0.8 \mathrm{~m}$ respectively. Processing of seismic data was carried out using Seismic Unix software, consisting of noise mute in the water column, automatic gain correction, band-pass filtering and swell filtering using a methodology developed at La Rochelle University [Chaumillon et al., 2008a]. A P-wave velocity of $1600 \mathrm{~m} \mathrm{~s}^{-1}$ was chosen for time-to-depth conversion (figs 5 to 13 ).
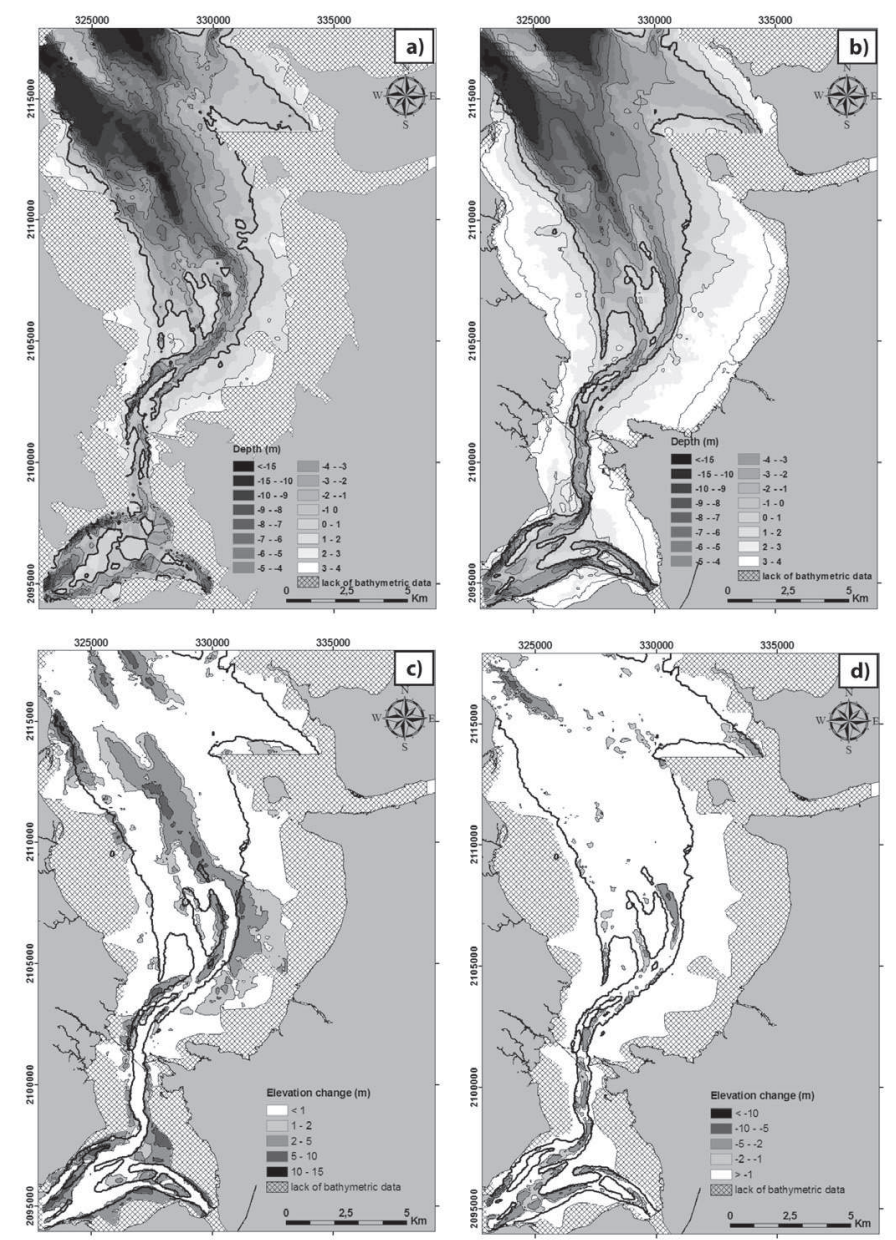

FIG. 4. - Bathymetric and differential maps of the Marennes-Oléron Bay The bold line indicates the $0 \mathrm{~m}$ isobath. (a) Digital elevation models of the bathymetry of 1824 and coastline of 1824. (b) Digital elevation models of the bathymetry of 2003 and coastline of 1997. (c) Positive sediment gain (net deposition) map between 1824 and 2003. (d) Negative sediment gain (erosion) map between 1824 and 2003.

FIG. 4. - Cartes bathymétriques et de différences bathymétriques de la baie de Marennes-Oléron. La courbe en gras indique le 0 hydrographique (marine chart-sounding datum). (a) Modèle numérique de terrain bathymétrique et trait de côte en 1824. (b) Modèle numérique de terrain bathymétrique et trait de côte en 2003. (c) Carte de gain sédimentaire entre 1824 et 2003. (d) Carte d'érosion sédimentaire entre 1824 et 2003.

Cores VC22, VC42 and VC47, collected during MOBIDYC 5 CNRS/INSU cruise (2006, R/V Côte de la Manche, fig. 1c) were sectioned longitudinally, lithologically described, photographed, X-radiographied [SCOPIX, Migeon et al., 1999], and sampled for grain-size analyses. Samples for grain-size analyses were collected from intervals where X-ray images and grey-level curves showed noticeable changes. Grain size analysis was conducted using a microgranulometer (Mastersizer S instrument, Malvern Instruments). Inman's [1952] classification was used to define the various grain-size fractions: clay and fine silt $(<15 \mu \mathrm{m})$, medium silt $(15-30 \mu \mathrm{m})$, coarse silt $(30-63 \mu \mathrm{m})$ and very fine sand $(>63 \mu \mathrm{m})$. Description of cores KV60 and VC48 are available in Weber [2004] and Allard et al. [2008], respectively.

The radiochronology is based on ten uncalibrated radiocarbon dates, obtained on shells of the bivalves Abra sp. 
(Poz-20105, Poz-20106, Poz-20121, Poz-20122, Poz-23454) Ostrea edulis (Poz-23455, Poz-23457), Cerastoderma edule (Poz-26304, Poz-26303) and Pandora inaequivalvis (Poz-26302). The AMS method was conducted in the Poznan Radiocarbon Laboratory, Poland. Samples were intact and thin shells of the bivalves.

\section{RESULTS}

For the description of the results obtained, the MOB is subdivided into two parts, namely, northern part (NMOB, fig. 1b) and southern part (SMOB, fig. 1b), which are developed on both sides of the narrow "Coureau d'Oléron" Strait (COS, fig. 1b). The NMOB is subdivided in a western (WMOB, fig. 2a) and an eastern part (EMOB, fig. 2a).

\section{Bathymetric results}

The net volume change between the 1824 and 2003 DEM was estimated over $70 \%$ of the total area of the MOB, which is $44 \%$ of the intertidal area and $100 \%$ of the subtidal area (figs $4 \mathrm{a}$ and $\mathrm{b}$ ). The sediment budget between 1824 and 2003 (179 years) was $+77 \pm 48 \times 10^{6} \mathrm{~m}^{3}$ (table I). The corresponding average sedimentation rate was about +3 $\pm 1.9 \mathrm{~mm} \cdot \mathrm{yr}^{-1}$ (table I). Sediment gain occurred mainly on tidal flats on both sides of the whole MOB and tidal channels of the NMOB (fig. 4c) whereas erosion was mainly restricted to the tidal channels of the SMOB (fig. 4d).

The net change in sediment volume on the intertidal zone of the MOB between 1824 and 2003 was about $+38 \pm 15 \times 10^{6} \mathrm{~m}^{3}\left(4.8 \pm 1.9 \mathrm{~mm} \cdot \mathrm{yr}^{-1}\right.$; table I). Sedimentation volumes and rates increase toward the head of the Bay: in the NMOB sediment accretion within intertidal zone was about $+17 \pm 12 \times 10^{6} \mathrm{~m}^{3}\left(2.7 \pm 1.9 \mathrm{~mm}_{\mathrm{yr}} \mathrm{yr}^{-1}\right.$; table I), whereas in the SMOB it was about $+21 \pm 3.5 \times 10^{6} \mathrm{~m}^{3}$ $\left(12 \pm 1.9 \mathrm{~mm} \cdot \mathrm{yr}^{-1}\right.$; table I). Maximum vertical accretion reached more than $10 \mathrm{~m}$ in a mixed flat within the western part of the NMOB and nearly $6 \mathrm{~m}$ in the mixed flat of the SMOB (fig. 4c).

The net change in sediment volume on the subtidal zone of the MOB between 1824 and 2003 was about $+39 \pm 33 \times 10^{6} \mathrm{~m}^{3}\left(2.3 \pm 1.9 \mathrm{~mm} \cdot \mathrm{yr}^{-1}\right.$; table I). In the NMOB, sediment accretion within subtidal zone was

TABLE. 1. - Sediment budgets and average sedimentation rates, calculated from difference bathymetric maps (1824-2003), of the whole, the subtidal and the intertidal zones of the MOB and of the whole, the sub-tidal and the inter-tidal zones of the northern and southern parts of the MOB. The boundaries of the northern and southern parts of the Mob are shown in figure 1.

TABL. 1. - Budgets sédimentaires et taux de sédimentation moyens, calculés à partir des différences de bathymétrie entre 1824 et 2003, pour la totalité et les zones inter et subtidales de la baie de Marennes-Oléron ainsi que pour la totalité et les zones inter-et subtidales des parties nord et sud de la baie de Marennes-Oléron (les limites des parties nord et sud de la baie de Marennes sont montrées dans la figure 1.

\begin{tabular}{|c|c|c|c|c|}
\hline \multirow[t]{2}{*}{ Location } & \multicolumn{2}{|c|}{$\begin{array}{l}\text { Net change in sediment volume } \\
\qquad\left(\times 10^{6} \mathrm{~m}^{3}\right)\end{array}$} & \multicolumn{2}{|c|}{$\begin{array}{l}\text { Sedimentation rate } \\
(\mathrm{mm} . \mathrm{yr}-1)\end{array}$} \\
\hline & Intertidal & Subtidal & Intertidal & Subtidal \\
\hline \multirow[t]{2}{*}{ MOB } & \multicolumn{2}{|c|}{$77 \pm 48$} & \multicolumn{2}{|c|}{$3 \pm 1.9$} \\
\hline & $38 \pm 15$ & $39 \pm 33$ & $4.8 \pm 1.9$ & $2.3 \pm 1.9$ \\
\hline \multirow{2}{*}{$\begin{array}{l}\text { North } \\
\text { MOB }\end{array}$} & \multicolumn{2}{|c|}{$60 \pm 40$} & \multicolumn{2}{|c|}{$3 \pm 1.9$} \\
\hline & $17 \pm 12$ & $43 \pm 28$ & $2.7 \pm 1.9$ & $3 \pm 1.9$ \\
\hline \multirow{2}{*}{$\begin{array}{l}\text { South } \\
\text { MOB }\end{array}$} & \multicolumn{2}{|c|}{$17 \pm 8$} & \multicolumn{2}{|c|}{$4.3 \pm 1.9$} \\
\hline & $21 \pm 3.5$ & $-4 \pm 4.5$ & $12 \pm 1.9$ & $-1.7 \pm 1.9$ \\
\hline
\end{tabular}

restricted to the main tidal channel (fig. 4c) and was about $+43 \pm 28 \times 10^{6} \mathrm{~m}^{3}\left(+3 \pm 1.9 \mathrm{~mm} \cdot \mathrm{yr}^{-1}\right.$; table I). Maximum vertical accretion could reach more than $8 \mathrm{~m}$ in the Rade des Trousses Channel. Sediments mainly consisted of mixed very fine sand and fine silts (figs. $1 \mathrm{~b}, 2 \mathrm{~b}$ and $4 \mathrm{c}$ ). The subtidal zone of the NMOB displays widely scattered areas of erosion, which are mainly located adjacent to accretion areas that correspond to channel migrations [Bertin et al., 2005]. At the scale of whole subtidal area of the SMOB, the sediment budget is almost in equilibrium: $-4 \pm 4.5 \times 10^{6} \mathrm{~m}^{3}$ (table I). Nevertheless, the channel bottoms locally show deepening of a few meters that could reach more than $8 \mathrm{~m}$ eastward of the Maumusson tidal inlet (fig. 4d).

\section{Seismic and core results}

Seismic profiles recorded within the different parts of the MOB provide evidence for the presence of twelve main seismic units overlying the Mesozoic bedrock (U0) that is locally exposed on the seafloor (fig. 2b). The structural contour map of the upper surface of Mesozoic bedrock EU0 (fig. 2c) [Chaumillon et al., 2008b] displays incisions that can be considered as small to intermediate valleys [cf. Ashley and Sheridan, 1994] ranging from few hundred of meters to more than $5 \mathrm{~km}$ in width and from few meters to more than $20 \mathrm{~m}$ in depth. The major valley axis lies in a north-south orientation. The valley tapers southward and has width of less than $1 \mathrm{~km}$ in the Coureau d'Oléron Strait (fig. $2 \mathrm{a}$ and $\mathrm{c}$ ).

\section{The western Marennes-Oléron Bay (WMOB)}

Seismic profiles indicate that four major seismic units overlie the Mesozoic bedrock in the WMOB (figs 5, 6 and 7). From base to top, these units are UT1, UT2, UT3 and UT4 [Chaumillon et al., 2004; Billeaud et al., 2005; Bertin and Chaumillon, 2005b]; the equivalent units were labelled Uaid1, Uaid2, Uaid3 and Uaid4sd in Chaumillon and Weber [2006].

Unit UT1 is composed of lense-shaped seismic sub-units with small lateral extent (figs 5 and 6). These sub-units are isolated from each other and typically present in the depression on the surface of the Mesozoic bedrock. They are characterised by high-angle oblique parallel reflectors (fig. 6). Northward of the MOB, basal progradational units, similar to those observed in the WMOB, are believed to consist of medium to coarse sand and are dated to $6105 \pm 35{ }^{14} \mathrm{C} \mathrm{yr}$ B.P. [Chaumillon and Weber, 2006].

Unit UT2 consists of a valley-fill, lying upon both the incised Mesozoic bedrock and Unit UT1 (figs 5, 6 and 7) and extends to the Rade des Trousses Channel (figs 8, 9). Its thickness varies from about 2 to $15 \mathrm{~m}$. The seismic facies is characterised by moderate to high-amplitude reflectors. Internal configuration consists of subhorizontal reflectors that dip gently toward the northwest or northeast in the northwestern part of the WMOB. Upper boundary of UT2 is an erosional unconformity (EU1; figs 6 and 7). Unit UT2 is correlated with shelly bioturbated very fine to fine sand (figs 6 and 7) that alternates with a few thin planar beds made of clay to fine silt (fig. 6). Two shells of Abra sp., collected in core M3VC60 at $3.58 \mathrm{~m}$ and M5VC22 at $3.02 \mathrm{~m}$ bsf (below seafloor), yielded ages of $3095 \pm 35{ }^{14} \mathrm{C}$ yr B.P. 


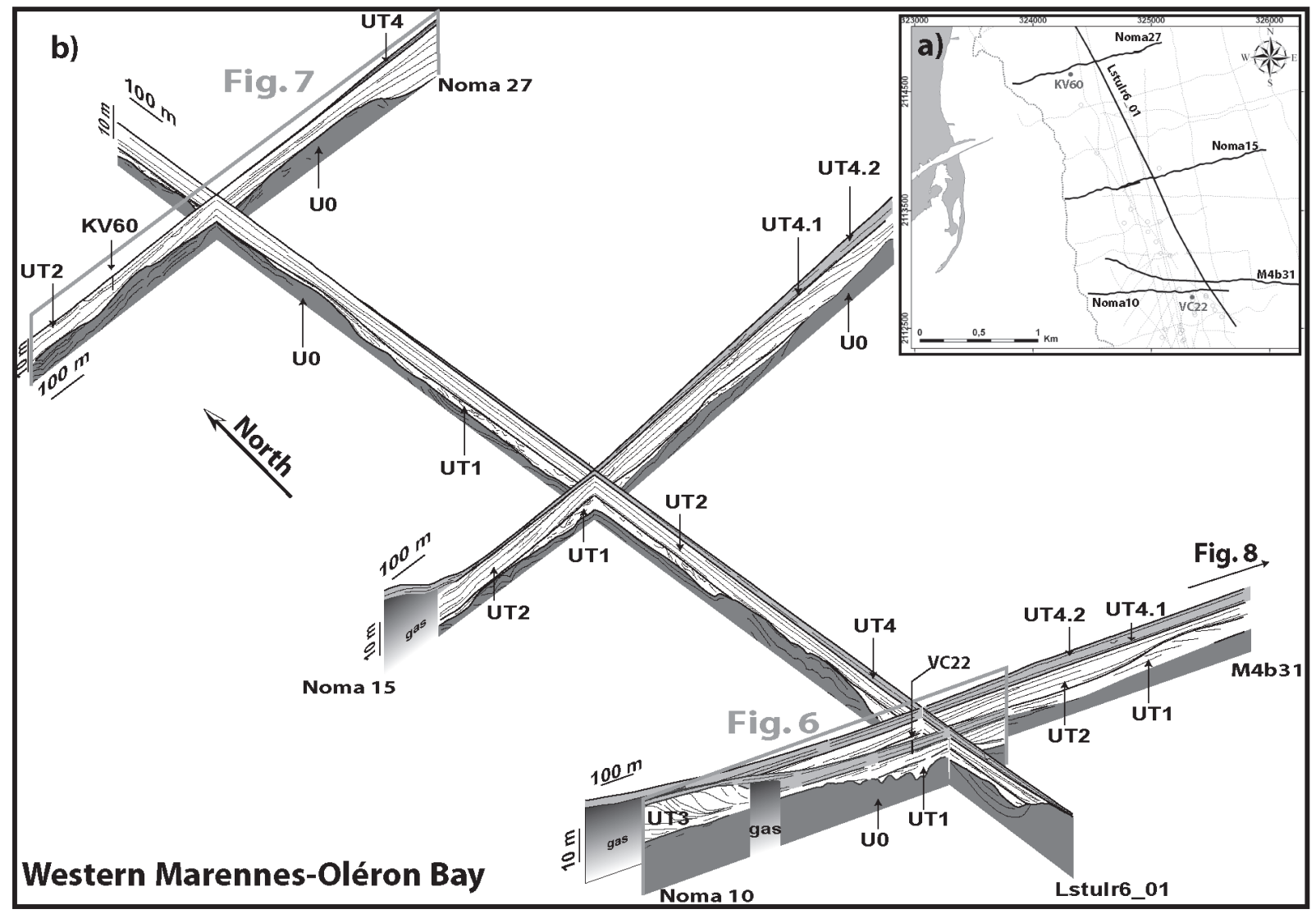

FIG. 5. - (a) Location map of the seismic profiles and cores within the western part of the Marennes-Oléron Bay. Bold lines and black circles indicate the seismic tracks and the vibracores shown in figure 5b. (b) Fence diagram of seismic profiles Noma27, Noma15, Noma10, M4b31 and Lstulr6_01, showing the internal architecture of the western part of the Marennes-Oléron Bay. Seismic unit U0 corresponds to the bedrock and seismic units UT1, UT2, UT3 and UT4 (UT4.1 and UT4.2) correspond to the unconsolidated sedimentary cover.

FIG. 5. - (a) Carte de localisation des profils sismiques et des carottes dans la partie ouest de la baie de Marennes-Oléron. Les traits gras et les cercles noirs indiquent les profils et carottages montrés dans la figure 5b. (b) Montage 3D des profils Noma27, Noma15, Noma10, M4b31 et Lstulr6 01, illustrant l'architecture interne du comblement sédimentaire dans la partie ouest de la baie de Marennes-Oléron. L'unité sismique U0 correspond au socle rocheux et les unités UT1, UT2, UT3 and UT4 (UT4.1 and UT4.2) correspondent à la couverture sédimentaire meuble.

(Poz-23454) and $1695 \pm 30{ }^{14}$ C yr B.P. (Poz-20106), respectively (figs 6 and 7).

UT3 consists of a bank lying upon unit UT2 (figs 5 and $6)$. The maximum thickness of unit UT3 reaches $12 \mathrm{~m}$. The internal configuration is progradational. This unit is composed of mixed of gravel, medium and fine sand and silt [Chaumillon et al., 2004]. Shells of Cerastoderma edule and Pandora inaequivalvis collected at the top of UT3 unit from three cores, M5VC33, 34 and 35 respectively located at 10,50 and $100 \mathrm{~m}$ of the previously published seismic profile NOMA16 [Chaumillon et al., 2004] yielded ages of $1235 \pm 30{ }^{14} \mathrm{C}$ yr B.P. (49 $\mathrm{cm}$ bsf in M5VC33, Poz-26304), $1165 \pm 30{ }^{14} \mathrm{C}$ yr B.P. (57 cm bsf in M5VC34, Poz-26302) and $1245 \pm 30{ }^{14} \mathrm{C}$ yr B.P. (104 cm in M5VC35, Poz-26303).

Unit UT4 consists of a sheet drape, lying upon both units UT2 and UT3 (figs 5, 6, 7) and extends to the EMOB (figs 8, 9, 10 and 11).

The base of UT4 corresponds to the erosional unconformity "EU1", which is correlated with a shell-bed and a sharp decrease of grain size upward [Chaumillon et al., 2004; Billeaud et al., 2005]. The maximum thickness of unit UT4 reaches up to $5 \mathrm{~m}$ and this unit thins progressively towards both the northwest and the southwest of the NMOB. Seismic facies consists of high-frequency and moderate-amplitude reflectors with a sub-parallel and sub-horizontal internal configuration. Upper surface of UT4 corresponds to the present-day seafloor. Unit UT4 is correlated with planar bedded fine silt and clay that alternate with bioturbated and shelly fine sand layers (figs 6,9). UT4 is associated with methane-rich sediment within the Rade des Trousses Channel (fig. 9) [Bertin and Chaumillon, 2005b; Roussel et al., 2009]. UT4 is subdivided into two sub-units, namely, UT4.1 and UT4.2 that are separated by a high-amplitude sub-horizontal reflector correlated with a shelly sand layer at $1.45 \mathrm{~m}$ bsf (fig. 6), where an Abra sp. yielded an age of $570 \pm 30{ }^{14} \mathrm{C}$ yr B.P. (Poz-20121). Another shell of Abra sp., collected in UT4.1 at $2.75 \mathrm{~m}$ bsf yielded an age of $910 \pm 30{ }^{14} \mathrm{C}$ yr B.P. (Poz-20122).

\section{The eastern Marennes-Oléron Bay}

Seismic profiles indicate five major seismic units overlying the Mesozoic bedrock (fig. 10). From base to top, these units are Ue1.1, Ue1.2, Ue2, Ue3 and UT4. In particular, Ue1.1, Ue1.2 and Ue3 correspond to U1.1, U1.2 and U3, respectively in Allard et al. [2008].

Ue1.1 and Ue1.2 consist of a valley-fill. Reflectors of unit Ue1.1 onlap the incised Mesozoic bedrock (U0). Unit 

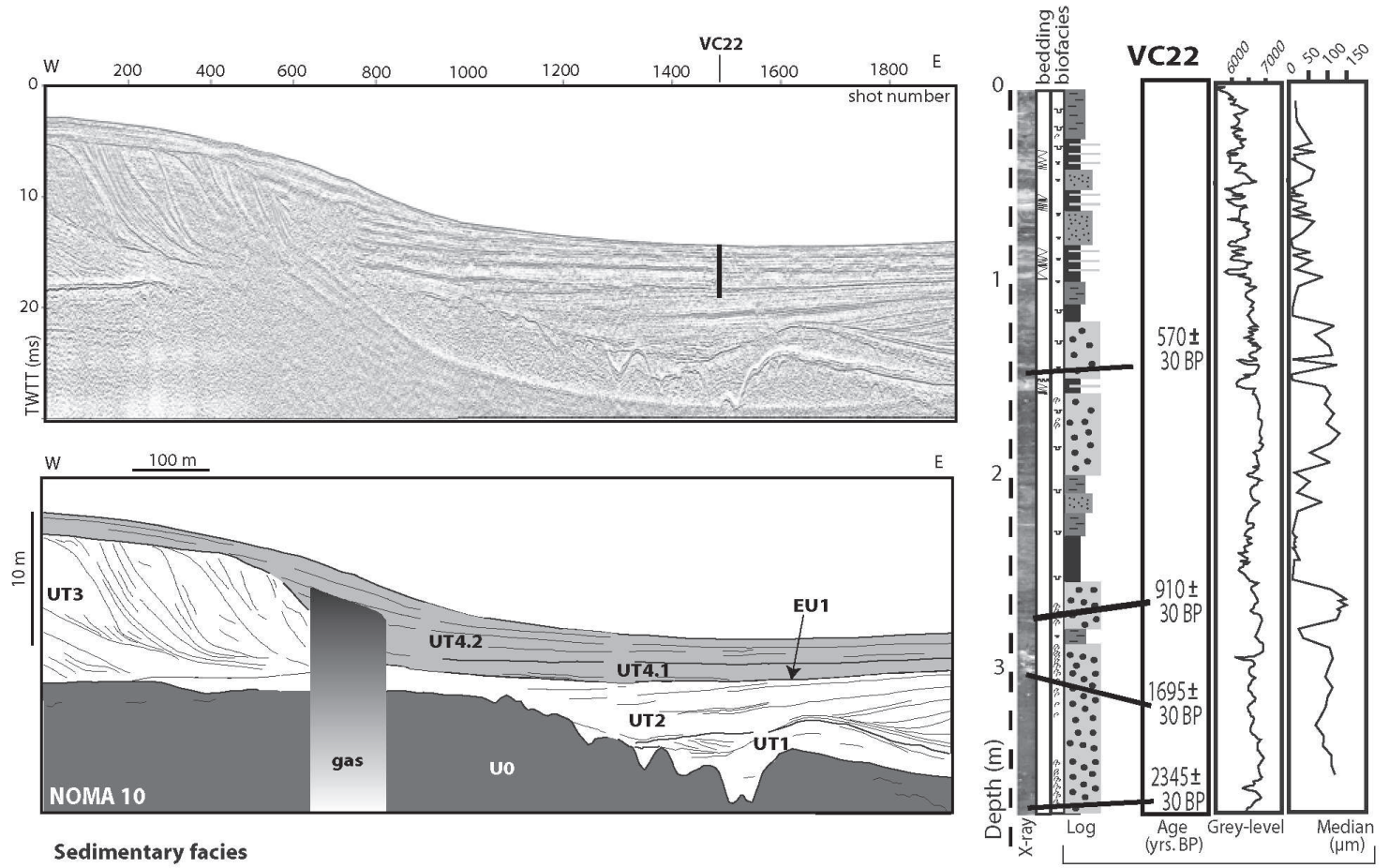

Sedimentary facies
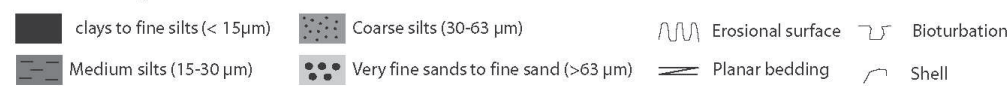

FIG. 6. - VHR seismic profile Noma10 and its interpretation showing the internal architecture of the sediment infilling within the western part of Marennes-Oléron Bay. Detailed description of vibracore VC22 include, from left to right: depth (m below seafloor: bsf), X-ray image, bedding and biofacies, grain size, ${ }^{14} \mathrm{C}$ uncalibrated dates, grey-level curve and median grain-size in micrometers.

FIG. 6. - Profil sismique Nomal0 et son interprétation montrant l'architecture interne du comblement sédimentaire de la partie ouest de la baie de Marennes-Oléron. La description de la carotte VC22 comprend de gauche à droite : la profondeur (en $m$ par rapport au fond marin), l'image RX, le litage et le biofaciès, la granularité, les âges non calibrés, la courbe de niveau de gris et la médiane de granularité en micromètres.
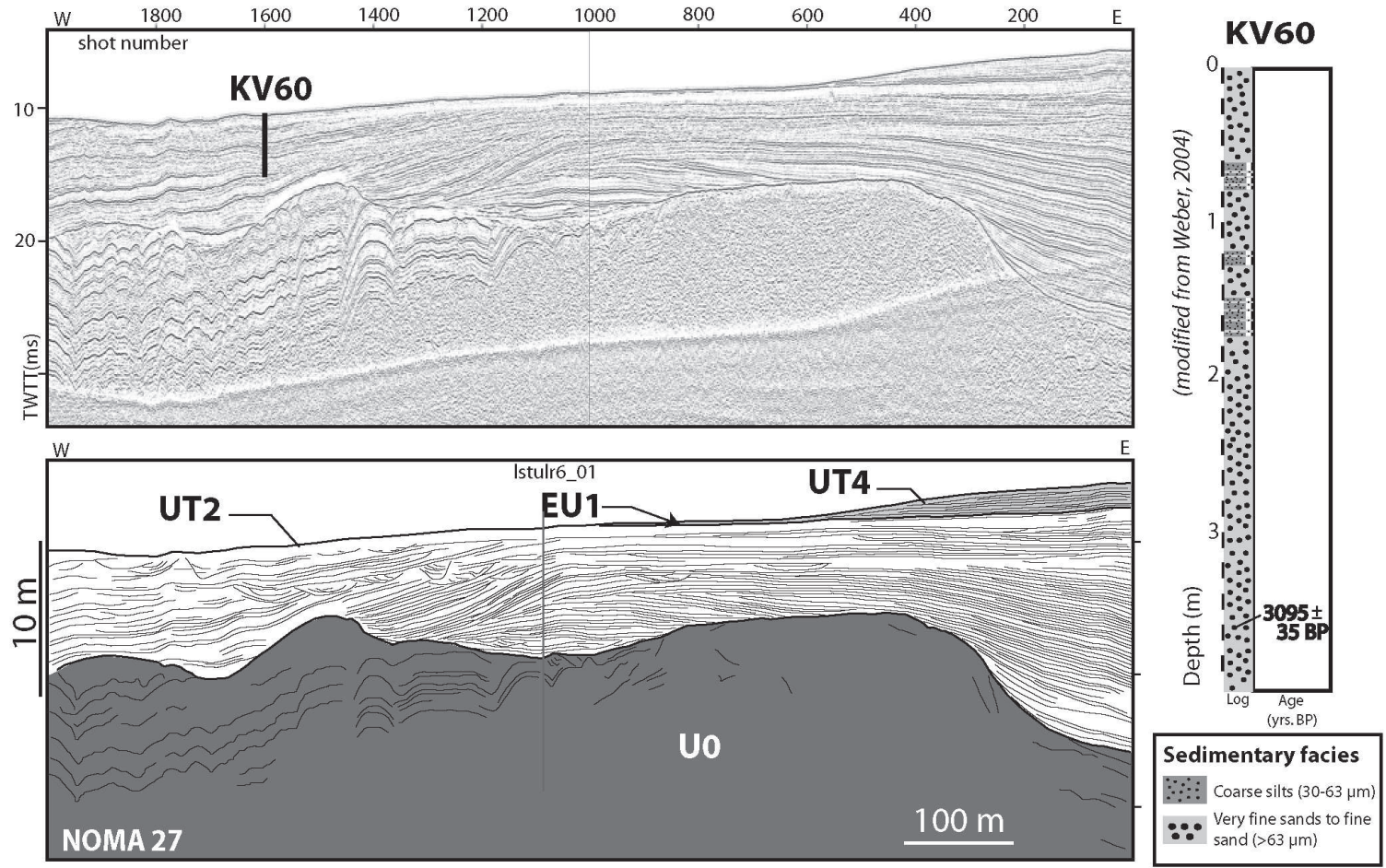

FIG. 7. - VHR seismic profile Noma27 and its interpretation showing the internal architecture of the sediment infilling within the western part of Marennes-Oléron Bay. Simplified description of vibracore KV60 [modified from Weber, 2004] is indicated, including from left to right: depth (m bsf], grain size, ${ }^{14} \mathrm{C}$ uncalibrated dates.

FIG. 7. - Profil sismique Noma27 et son interprétation montrant l'architecture interne du comblement sédimentaire de la partie ouest de la baie de Marennes-Oléron. Description simplifiée de la carotte KV60 [modifié d'après Weber, 2004] avec de gauche à droite : la profondeur (en m par rapport au fond marin), la granularité, les âges non calibrés. 


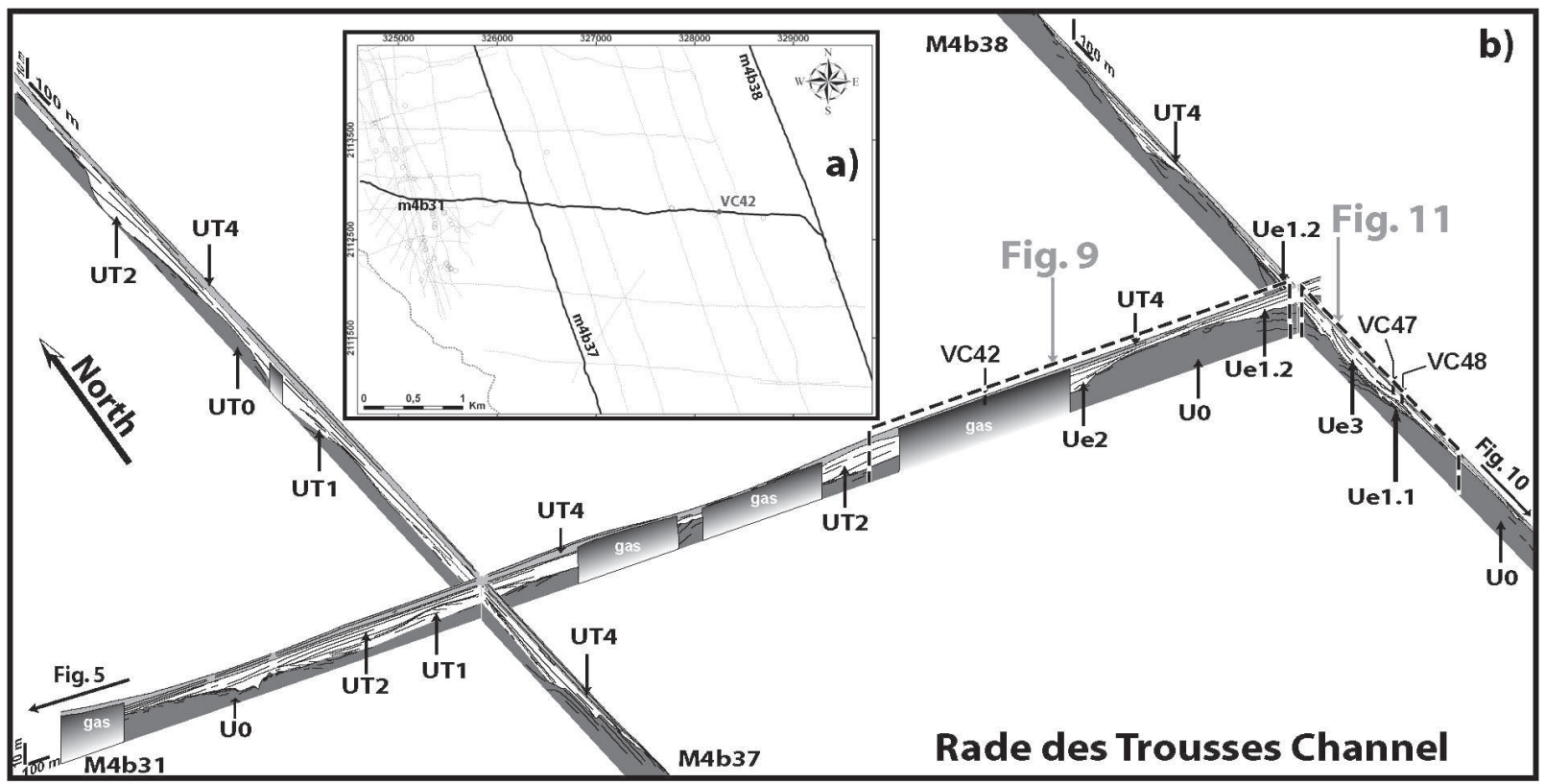

FIG. 8. - (a) Location map of seismic profiles (Bold dark lines indicate the seismic profiles shown in this study) and vibracore (circles) within the Rade des Trousses Channel. (b) Fence diagram of seismic profiles M4b31, M4b37 and M4b38, showing the internal architecture of the Rade des Trousses Channel at the transition between the WMOB and the EMOB. Seismic unit U0 corresponds to the bedrock and seismic units UT1, Ue1.1, Ue1.2, Ue2, Ue3, UT2, and UT4 (UT4.1 and UT4.2) correspond to the soft sedimentary cover.

FIG. 8. - (a) Carte de localisation des profils sismiques (les profils montrés dans cette étude sont représentés en gras) et des carottes (cercles) dans la rade des Trousses. (b) Montage 3D des profils M4b31, M4b37 et M4b38, illustrant l'architecture interne du comblement sédimentaire dans la rade des Trousses. L'unité sismique UO correspond au socle rocheux et les unités UT1, Ue1.1, Ue1.2, Ue2, Ue3, UT2, and UT4 (UT4.1 and UT4.2) correspondent à la couverture sédimentaire meuble.

Ue1.1 thickness varies from 2 to $5 \mathrm{~m}$. Seismic facies is characterised by low amplitude reflectors. Internal geometry consists of a divergent valley-fill (fig. 11).

Unit Ue1.2 overlies U1.1 and onlap the Mesozoic bedrock (U0, fig. 11). Ue1.2 thickness varies from 1.5 to $4.5 \mathrm{~m}$. The seismic facies is characterised by low-to-middle amplitude reflectors. Internal geometry consists of gently undulating and sub-parallel reflectors. Ue1.2 is correlated with clay and fine silt including intertidal mudflat species. Two shells of Scrobicularia plana $(-4.1 \mathrm{~m}$ bsf) and Loripes lacteus $\left(-2.3 \mathrm{~m}\right.$ bsf) yielded ages of $8030 \pm 50{ }^{14} \mathrm{C}$ yr B.P. and $7610 \pm 40{ }^{14} \mathrm{C}$ yr B.P. respectively [Allard et al., 2008] (fig. 11).

Unit Ue2 consists of a drape lying on Ue1.2 unit and on the slope of the Mesozoic bedrock. Seismic facies is transparent (fig. 9).

Unit Ue3 consists of a channel-fill downcutting Ue1.1 and Ue1.2. The maximum thickness of Ue3 is about $8 \mathrm{~m}$ (fig. 11). Seismic facies is characterised by high frequency, middle to high amplitude reflectors. Internal geometry is a complex channel-fill. Unit Ue3 is correlated with shell beds dominated by Ostrea edulis associated with medium to coarse silt (fig. 11). Two shells of $O$. edulis $(-2.3 \mathrm{~m}$ and $-3.5 \mathrm{~m}$ bsf) yielded ages of $5130 \pm 35{ }^{14} \mathrm{C}$ yr B.P. (Poz-23455) and $5560 \pm 40{ }^{14}$ C yr B.P. (Poz-23457).

The upper UT4 unit (fig. 11) has been already described in section 4.2.1. In the EMOB, UT4 lies upon the erosional unconformity, "EU1", located at the top of Ue1.2, Ue2 and Ue3 (fig. 9 and 11) and is correlated with a 0.5 m-thick bed composed of shelly very fine sand deposit [Allard et al., 2008]. A shell of Abra sp. located within UT4.1 at $0.84 \mathrm{~m}$ bsf yielded an age of $630 \pm 30$ years ${ }^{14} \mathrm{C}$ yr B.P. [Poz-20250; Allard et al., 2008].

\section{The southern Marennes-Oléron Bay}

Seismic profiles indicate four major seismic units overlying the Mesozoic bedrock (fig. 12). From base to top, these units are Us1, Us2, Us3 and Us4.

Unit Us 1 consists of a 10 m-thick progradational body with moderate lateral extent (about $1500 \mathrm{~m}$ wide), which partly fills a major incision within the Mesozoic bedrock (fig. 12). Internal configuration of Us1 is oblique tangential. Seismic facies is characterised by low frequency and low amplitude reflectors with moderate continuity (fig. 13).

Unit Us 2 consists of banks with few $\mathrm{m}$ to $10 \mathrm{~m}$ thickness and 200 to $1000 \mathrm{~m}$ width, lying upon both the Mesozoic bedrock and unit Us1 (fig. 12). Internal configuration of Us2 is oblique parallel. Seismic facies is characterised by small amplitude and high frequency with reflectors of low continuity. Locally the upper part of Us2 and its top surface is correlated with medium sand (fig. 13).

Us 3 consists of banks with few $m$ to 10-12 m thickness and few hundred of meters to few kilometres width, lying upon the Mesozoic bedrock and units Us1 and Us2. Internal configuration of Us3 is mainly oblique parallel and locally includes small channel-fills. Seismic facies is characterised by small amplitude and high frequency reflectors with low continuity (fig. 13). The top of those banks corresponds to the present-day seafloor and is correlated with medium sand and locally with mixed sand and mud (fig. 2b). Superimposition of 1824 bathymetric cross-sections on seismic 


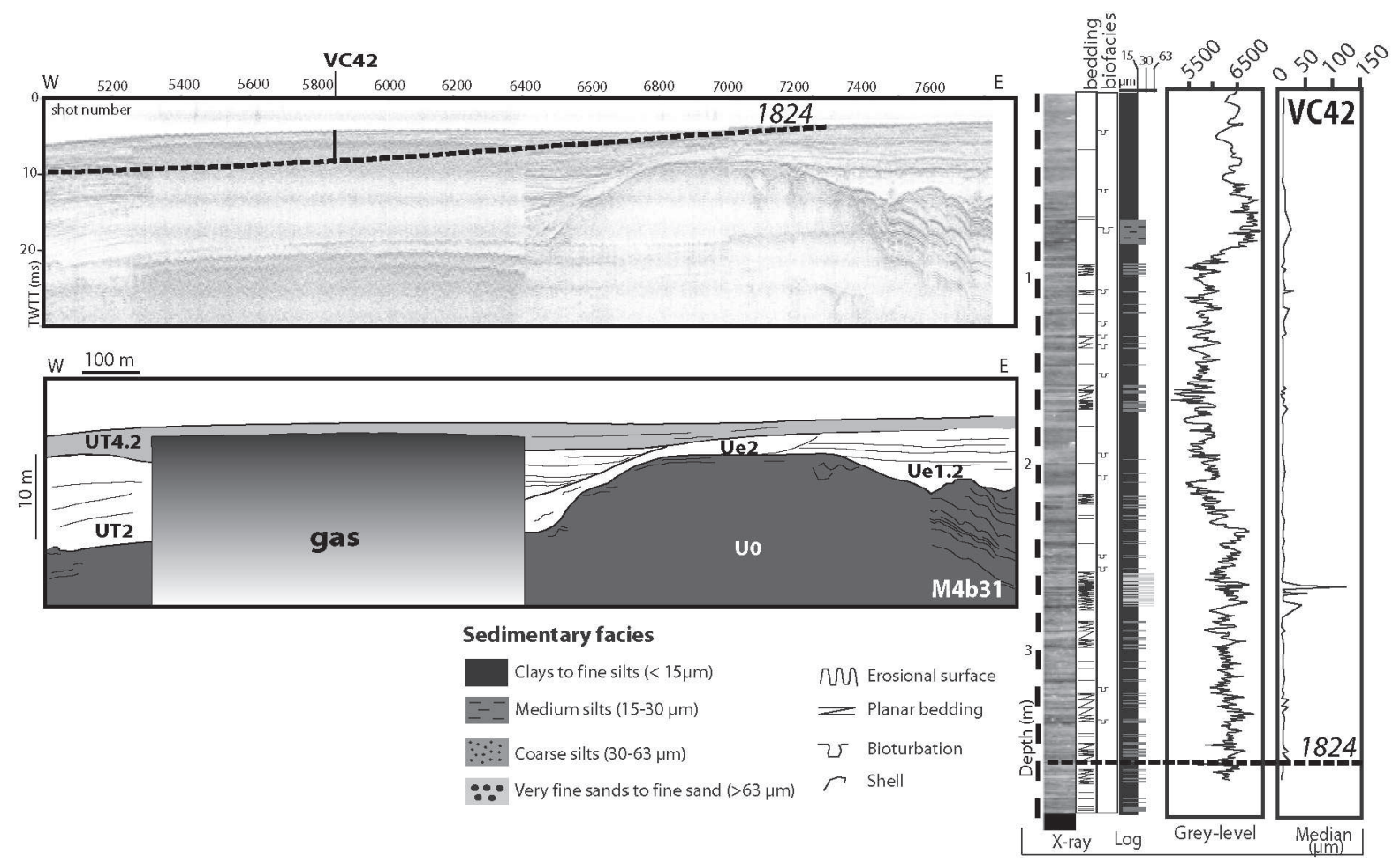

FIG. 9. - VHR seismic profile M4b31 and its interpretation showing the internal architecture of the sediment infilling within the Rade des Trousses Channel. Detailed description of vibracore VC42 includes from left to right: depth ( $\mathrm{m}$ bsf), X-ray image, bedding and biofacies, grain size, grey-level curve and median grain-size in micrometers. Seabottom of 1824 is indicated thank to a dashed line on both seismic profile and VC42 core description.

FIG. 9. - Profil sismique M4b31 et son interprétation montrant l'architecture interne du comblement sédimentaire dans la rade des Trousses. La description de la carotte VC42 comprend de gauche à droite : la profondeur (en m par rapport au fond marin), l'image RX, le litage et le biofaciès, la granularité, la courbe de niveau de gris et la médiane de granularité en micromètres. Le fond marin en 1824 est indiqué par une ligne pointillée à la fois sur le profil sismique et sur la carotte VC42.

profiles (figs 12 and 13) shows that a large part of those banks was deposited since the onset of the 19th century.

Unit Us 4 consists of a complex channel-fill that is $10 \mathrm{~m}$ thick and more than $1 \mathrm{~km}$ wide. Individual channel-fills observed within Us4 are a few meters deep and 100 to $300 \mathrm{~m}$ wide. Seismic facies is characterised by small amplitude and high frequency reflectors with low continuity (fig. 13). The top of Us4 corresponds to the present-day seafloor and can be correlated with mixed fine sand and mud (fig. $2 b$ ). Superimposition of 1824 bathymetric cross-sections on the seismic profile (fig. 13) shows this unit mainly arose after the beginning of the 19 th century.

\section{DISCUSSION}

\section{Secular evolution}

Volume computations based on careful comparison of recent bathymetric chart of 2003 with that of 1824 in the MOB indicate that there has been a positive sediment budget between 1824 and 2003. The computed volume difference is $+77 \pm 48 \times 10^{6} \mathrm{~m}^{3}$ which differs from the $+106 \times 10^{6} \mathrm{~m}^{3}$ value estimated by Bertin et al. [2005]. This difference is due to the choice of the mask analysis contour (fig. 4), which excludes the Maumusson Inlet, the Seudre River, the upper tidal flats and land areas reclaimed since 1824 (fig. 4).
The morphological evolution of the NMOB is different from that of the SMOB. The NMOB displays sediment gain in both intertidal and subtidal areas whereas the SMOB displays sediment gain only in the intertidal area. Sediment loss is inferred in the subtidal channels of SMOB, where channel depth increased.

Contrasting style of morphologic evolution between NMOB and SMOB can be related to the hydrodynamics of the MOB. It has been shown theoretically that flood-dominated estuaries become shallower and that ebb-dominated estuaries maintained with time due to tidal distortion [Friedrichs and Aubrey, 1988]. Due to the connection of the MOB with the ocean at both north and south of Oléron Island (fig. 1), there is an asymmetry between the ebb and flood tidal prisms and tidal durations at the entrances of the bay. Flood dominance is observed at the northern entrance [Tesson, 1973; Bertin et al., 2005] while ebb dominance is observed at the southern Maumusson Inlet [Bertin et al., 2004 and 2005]. The former is supported by the presence of flood-dominated sandbanks, the Longe de Boyard [Chaumillon et al., 2008a] and the Lamouroux sandbank (fig. 1b) [Bertin, 2005] in the NMOB, whereas the latter is supported by the occurrence of an ebb-dominated tidal Inlet in the SMOB [Bertin et al., 2004]. Nevertheless, unlike in Friedrichs and Aubrey [1988], ebb-dominance in the SMOB is related to disequilibrium in tidal prisms and does not result from tidal distorsion. By analogy with Friedrichs and Aubrey [1988], sediment gain within the whole NMOB can 


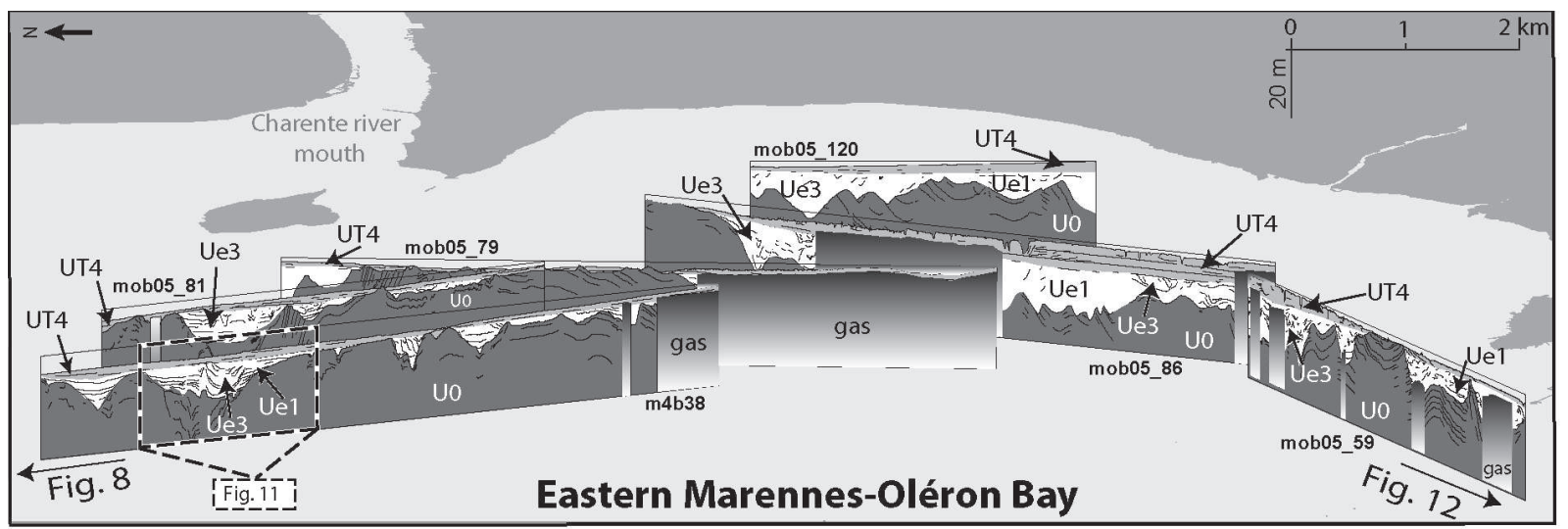

FIG. 10. - Fence diagram of seismic profiles M4b38, Mob05_59, Mob05_79, Mob05_81, Mob05_86 and Mob05_120, showing the internal architecture of the EMOB. Seismic unit U0 corresponds to the bedrock and seismic units Ue1.1, Ue1.2, Ue3 and UT4 correspond to the soft sedimentary cover. FIG. 10. - Montage 3D des profils M4b38, Mob05 59, Mob05 79, Mob05_81, Mob05 86 et Mob05 120, illustrant l'architecture interne du comblement sédimentaire dans la partie est de la baie de Marennes-Oléron. L'unité sismique U0 correspond au socle rocheux et les unités Ue1.1, Ue1.2, Ue3 and UT4 correspondent à la couverture sédimentaire meuble.

be explained by its flood-dominance. On the contrary, channel deepening in SMOB may result from a dynamic response to aggradation of intertidal flats, thus maintaining hydraulic efficiency.

A strong correlation between areas of sediment gain in the intertidal areas since 1824 and the position of oyster farms has been already pointed out by Bertin and Chaumillon [2006]. Those areas have been estimated to be
$35 \times 10^{6} \mathrm{~m}^{3}$ that is close to the net changes of $+38 \pm 15 \times$ $10^{6} \mathrm{~m}^{3}$ within the whole intertidal zone of the MOB. This correlation together with the work of Sornin [1981], which showed that oysters directly contribute to sedimentation of fine particles, by creating obstacles to currents favouring their decantation, indicate that, at a secular time scale, oyster farming may contribute significantly to the positive sediment budget of the bay.

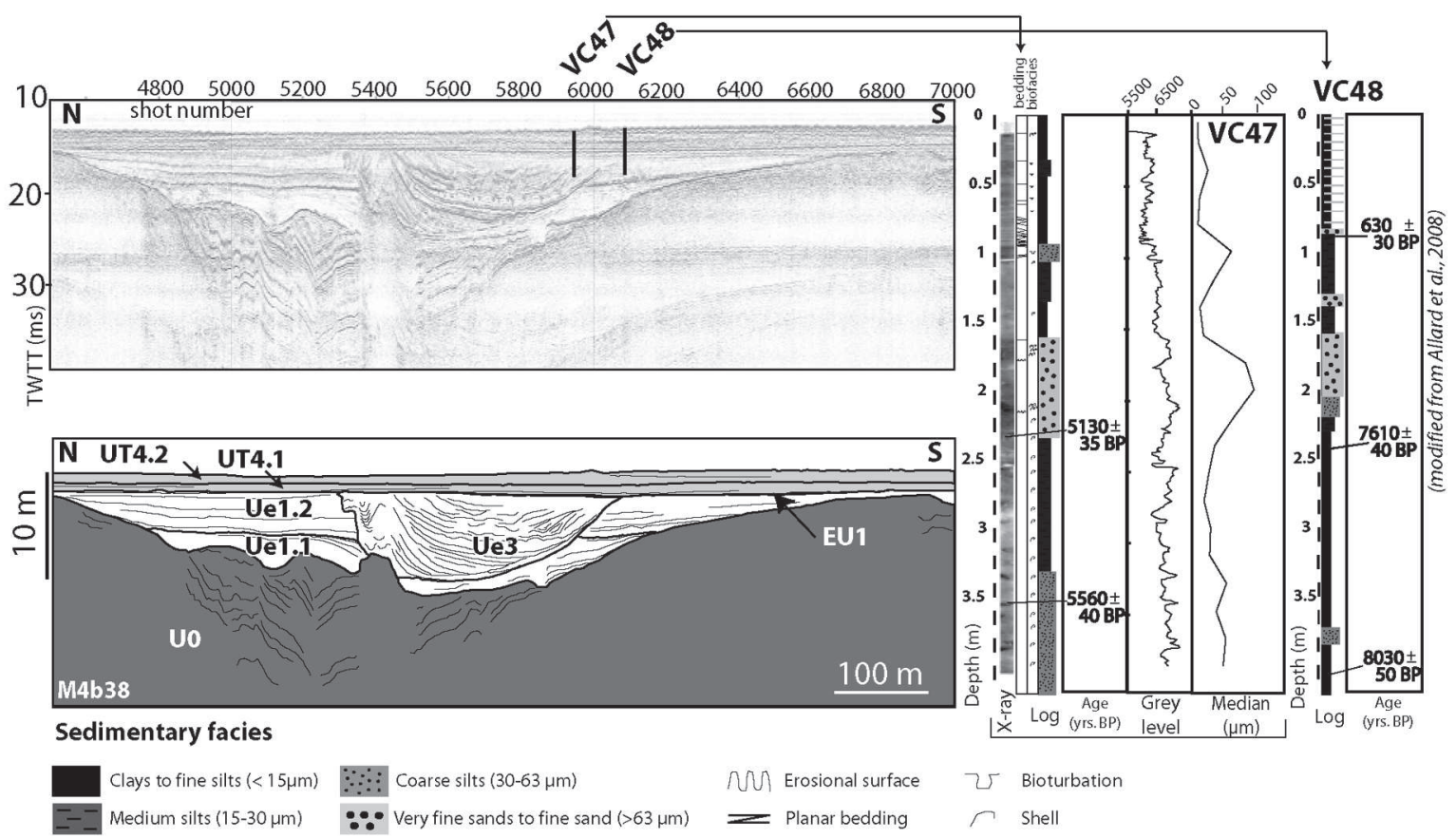

FIG. 11. - VHR seismic profile M4b38 and its interpretation showing the internal architecture of the sediment infilling within the EMOB. Detailed description of vibracores VC48 [modified from Allard et al., 2008] and VC47 includes from left to right: depth (m bsf], X-ray image, bedding and biofacies, grain size, ${ }^{14} \mathrm{C}$ uncalibrated dates, grey-level curve and median grain-size in micrometers.

FIG. 11. - Profil sismique M4b38 et son interprétation montrant l'architecture interne du comblement sédimentaire dans la partie est de la baie de Marennes-Oléron. La description des carottes VC48 [modifié d'après Allard et al. 2008] et VC47 comprend de gauche à droite : la profondeur (en $m$ par rapport au fond marin), l'image $R X$, le litage et le biofaciès, la granularité, les âges ${ }^{14}{ }^{C}$ non calibrés, la courbe de niveau de gris et la médiane de granularité en micromètres. 


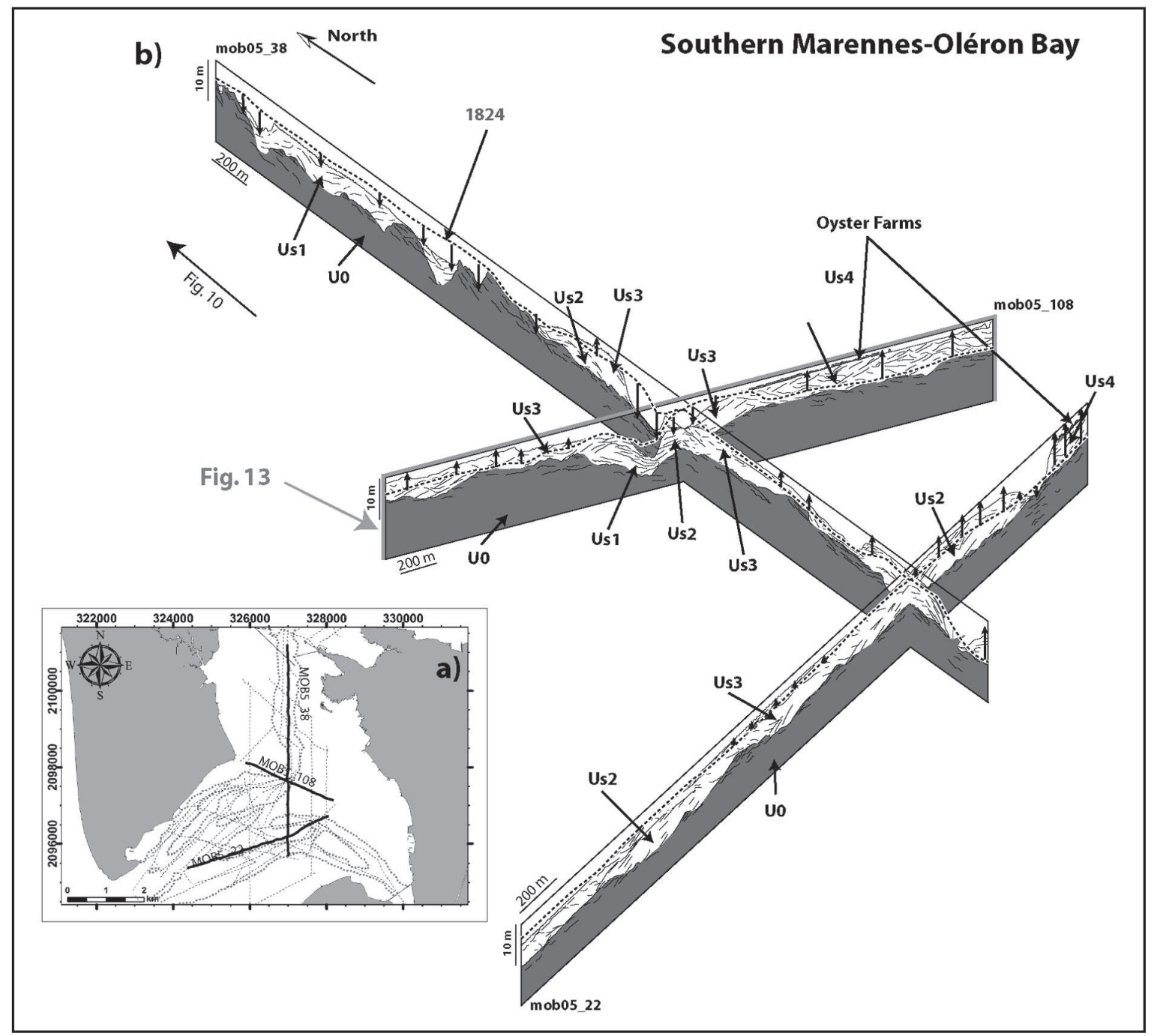

FIG. 12. - (a) Location map of the seismic profiles within the SMOB (bold dark lines indicate the seismic tracks discussed in this study). (b) Fence diagram of seismic profiles Mob05_22, 38 and 108, showing the internal architecture of the SMOB. Seismic unit U0 corresponds to the bedrock and seismic units Us1, Us2, Us3 and Us4 correspond to the soft sedimentary cover. Seabottom of 1824 is indicated thank to a dashed line and show that the main seismic units of the SMOB have been deposited over the last two centuries.

FIG. 12. - (a) Carte de localisation des profils sismiques dans la partie sud de la baie de Marennes-Oléron (les profils utilisés dans cette étude sont représentés en gras). (b) Montage 3D des profils Mob05_22, 38 and 108, illustrant l'architecture interne du comblement sédimentaire de la partie sud de la baie de Marennes-Oléron. L'unité sismique U0 correspond au socle rocheux et les unités Us1, Us2, Us3 et Us4 correspondent à la couverture sédimentaire meuble. Le fond marin en 1824 (ligne pointillée) montre les dépôts mis en place depuis cette époque.

\section{Millenial evolution of the Marennes-Oléron Bay}

Combined analysis of seismic profiles and sedimentary core results allows distinguishing five sediment infilling stages within the MOB (fig. 14).

\section{Stage 1: Early Holocene phase (before 7500 years B.P.)}

Given that occurrence of modern mudflats between $-3.5 \mathrm{~m}$ and $+2.5 \mathrm{~m} \mathrm{NGF}$, both its intertidal-flat origin and occurrence depth of around $-11 \mathrm{~m} \mathrm{NGF}(-7.5 \mathrm{~m}$ with reference to the marine chart-sounding datum at La Rochelle Harbour) are suggestive of that seismic unit Ue1.2 belongs to the transgressive systems tract (TST) [Allard et al., 2008]. Underlying seismic unit Ue1.2 has similar seismic characters and is also interpreted to belong to the TST. Basal lense-shaped sub-units UT1 have not been dated but may belong to either the lowstand or transgressive systems tracts.

\section{Stage 2: About 7500 to 5000 years B.P.}

Seismic unit Ue3 is interpreted as tidal channel-fills belonging to a former E-W tidal channel network related to the drainage of the Brouage Marsh area (figs 2b and 10). Given the available radiocarbon dates of the channel-fill and underlying units, both the incision and infilling of this channel have occurred between around 7500 years ${ }^{14} \mathrm{C}$ yr B.P. to 5500 years ${ }^{14} \mathrm{C}$ yr B.P. In the surrounding marshes, this period of time corresponds to a succession including marine sand at the base and intertidal silt at the top [Carbonel et al., 1998; Decker et al., 2001: Weber et al., 2004a], representing the end of the transgression and the beginning of the regression respectively. Given their orientation (fig. 2c) and 


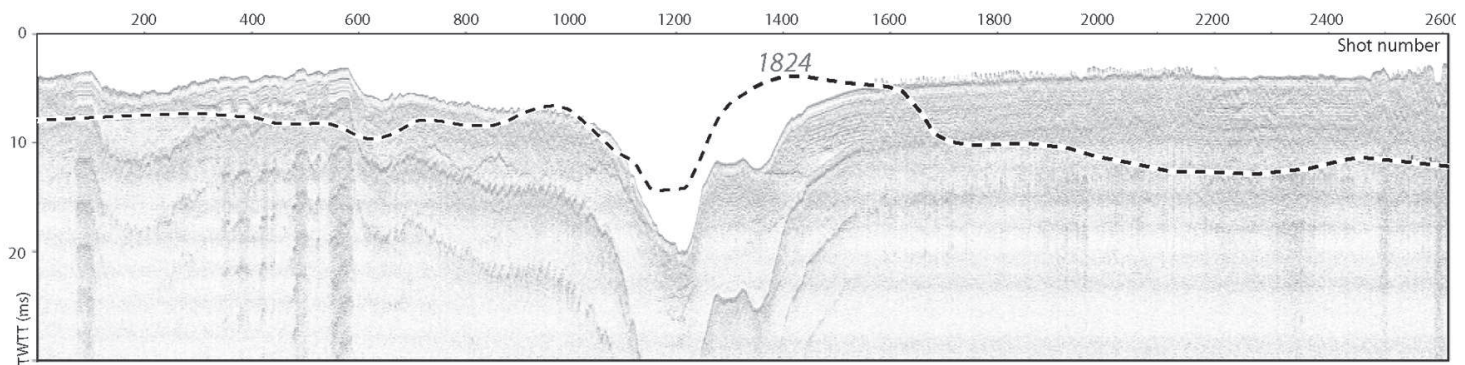

$$
\text { NW }
$$

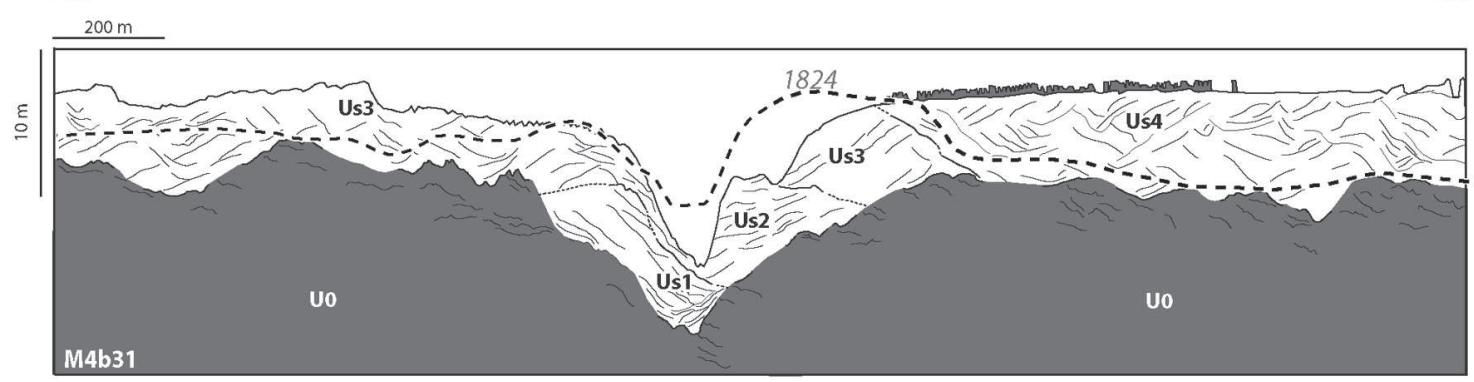

FIG. 13. - VHR seismic profile Mob05_108 and its interpretation showing the internal architecture of the sediment infilling within the SMOB. Seabottom of 1824 is indicated with a dashed line. Oyster farm installations (in grey) are observed on top of Us4 unit.

FIG. 13. - Profil sismique Mob05_108 et son interprétation montrant l'architecture interne du comblement sédimentaire dans la partie sud de la baie de Marennes-Oléron. Le fond marin en 1824 est indiqué par une ligne pointillée. Les installations ostréicoles (en gris) sont localisées au sommet de l'unité Us4.

the age of their sediment-fill, tidal channels corresponding to seismic units Ue3 may have been filled following a decrease in the tidal prism and current speeds in response to the sediment-fill of the Brouage marsh (fig. 2a) and associated coastline progradation. As Ue3 is synchronous with a regressive phase in the marshes, it is interpreted as the early highstand systems tract (HST).

\section{Stage 3: About 5000 to 1500 years B.P.}

In the WMOB, seismic unit UT2 consists of the bulk of the valley-fill in the WMOB. Internal configuration of UT2 is aggradational. Considering that the inferred age of UT2 is younger than the regressive channel-fill of Ue3 (stage 2), UT2 can be interpreted as regressive subtidal deposits belonging to the HST. This interpretation differs from that of Chaumillon and Weber [2006], which interpreted UT2 as the TST, based on the fact that the stepped morphology of time-equivalent the Pertuis Breton sediment-fill (few kilometers north of the MOB) was formed in response to sea-level rise [Weber et al., 2004b]. However the application of the Vail model [Vail et al., 1991], which locates the TST/HST contact at the change from onlapping reflectors to seaward prograding reflectors, at the scale of very high resolution seismic (less than $1 \mathrm{~m}$ of vertical resolution) lead to great complexity as progradational parasequences may occur in both the TST and HST [Carter et al., 1998] and as simultaneous progradation and retrogradation may occur simultaneously in different parts of the same estuarine system [Allen and Posamentier, 1994; Dalrymple and Zaitlin, 1994]. Therefore, the end of onlap is not a correct criterion for the TST-HST boundary in very high-resolution seismic studies.

\section{Stage 4: From 1500 to 1000 years B.P.}

The seismic boundary EU1 is an erosional unconformity correlated with a shell bed and a marked grain-size change. Meanwhile, although EU1 is almost flat at a kilometer-scale (fig. 6, 7, 9, 11) [Chaumillon et al., 2004; Billeaud et al., 2005], it appears as a channelized erosional unconformity at the scale of the entire NMOB (fig. 2d). There was a communication between the Gironde estuary and the SMOB (fig. 3) around $1100 \mathrm{yr}$ B.P., and it is assumed that in this palaeogeographical setting, tidal ravinement was more intense and may have induced EU1. This communication between the Gironde estuary and the SMOB was filled and the Maumusson Inlet opened since around 500 yr B.P.

\section{Stage 5: From about 1000 years B.P. to present-day}

In the NMOB, the uppermost seismic unit UT4 corresponds to a sheet drape composed of silt, the base of which is dated to $910 \mathrm{yr}$ B.P. This drape shows a sharp grain size decrease relative to underlying units and has been interpreted as recording an increase in mud supply mainly in response to deforestation and suspended matter migration related to land reclamation during the middle age [Chaumillon et al., 2004; Billeaud et al., 2005; Chaumillon and Weber, 2006].

In the SMOB and in the Coureau d'Oléron area (fig. 2a), the UT4 mud drape is absent. Seismic units Us1, 2, 3 and 4 are not correlated with cores but superimposition of bathymetric cross sections of 1824 on seismic profiles shows that a large part of the SMOB infill (Us3 and 4) has been emplaced during the last two centuries (figs 12 and 13). Units Us 1, 2 and 3 are considered as sandbanks. Given that Us1 and 2 are deposited before 1824, they are 
interpreted as sandbank cores similar to the core of the Longe de Boyard at the northern entrance of the MOB [Chaumillon et al., 2008a]. Us3 represents active modern sandbanks, associated with the tidal flux through the Maumusson Inlet. Unit Us4 consists of a channel fill mainly emplaced after the beginning of the 19th century and is interpreted as recording tidal channel abandonment because its orientation made it hydraulically inefficient (figs. 4a and c and 13). This abandoned channel may be related to the old drainage network associated with the communication between the MOB and the Gironde during the Middle Age (fig. 3).

\section{Controlling factors of a tidal bay-fill}

From this study it appears that the sediment-fill of the MOB is thin and complex and has been controlled by several factors through time.

The basal eastern bay-fill consists of drowned intertidal flats, which was thus partly controlled by the last sea-level rise [Allard et al., 2008].

Those drowned flats are located in intermediate-sized valleys that are filled with sediment because they are sub perpendicular to the main valley where lies the present-day main tidal channel and where scour may have removed some or all of the transgressive sediment. The location of preserved transgressive deposits in those intermediate valleys indicates that the bedrock morphology (including the depth of incision and the valley orientation) has played a role in sediment preservation after the sea level rose. Bedrock control on sediment dynamic and stratigraphy is also evidenced in the SMOB where some present-day tidal channels are anchored in bedrock incisions (fig. 12), as has already been shown for the Maumusson Inlet [Bertin et al. 2004].

The location of preserved drowned flats in the EMOB can also be related to tidal drainage reorientation (from a West-East orientation to a present-day North-South orientation), which was induced by the infilling of surrounding marshes (fig. 2) that have prevented tidal ravinement in this area. Tidal currents also control the secular infilling of the bay as the NMOB morphological evolution can be explained by its flood dominance whereas channel deepening and aggradation of intertidal flats in the SMOB can be explained by its ebb dominance. Secular infilling of the bay is also controlled by waves near the entrances of the Bay as attested by the formation of several sandspits during the last two centuries [Bertin et al., 2005].

The suspended matter that have filled the MOB does not only originate from the Charente River (mean annual solid discharge: 41000 t. $\mathrm{yr}^{-1}$, Gonzalez et al., 1991], but also
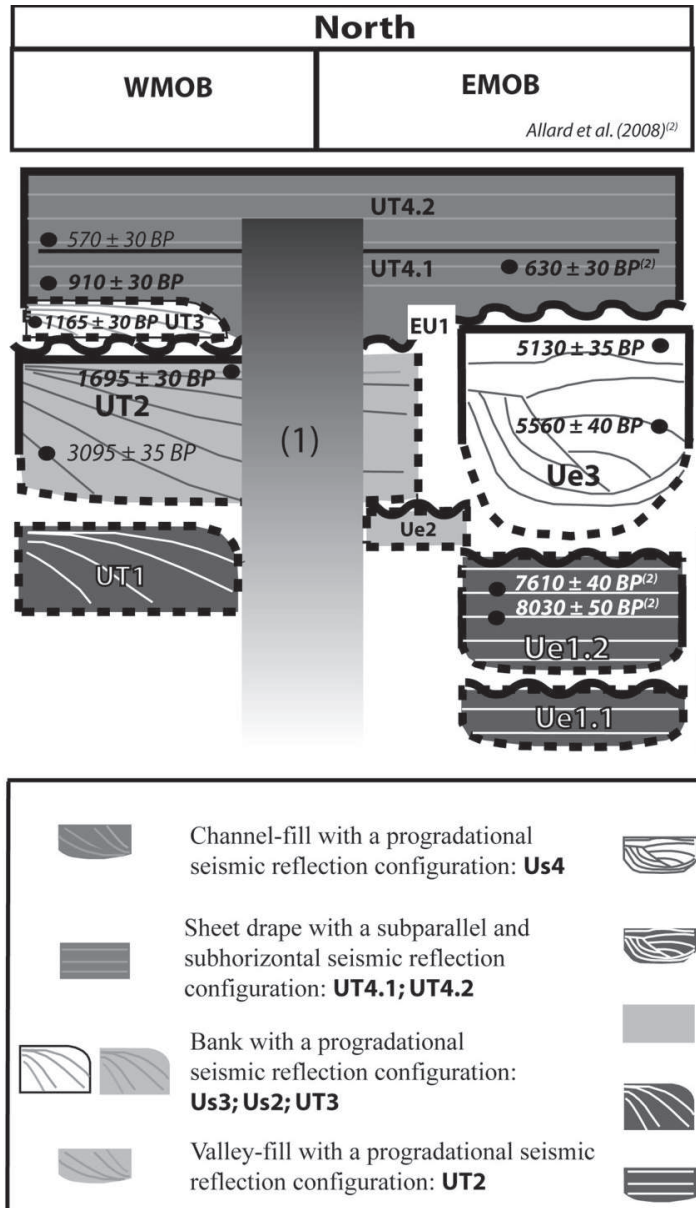

\begin{tabular}{|c|}
\hline South \\
\hline SMOB \\
\hline
\end{tabular}

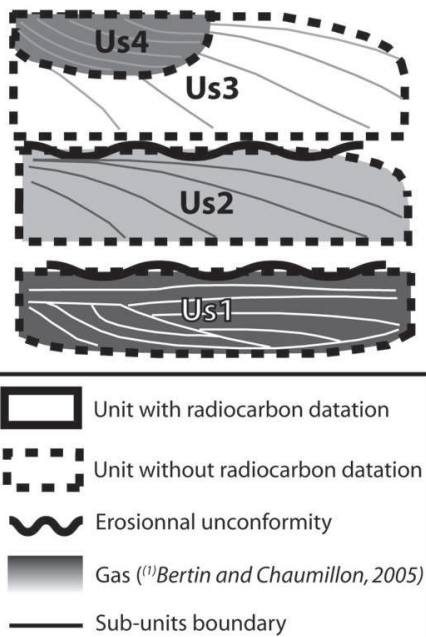

Channel-fill with a complex seismic reflection configuration: Ue3

Valley-fill with a complex seismic reflection configuration: Us?

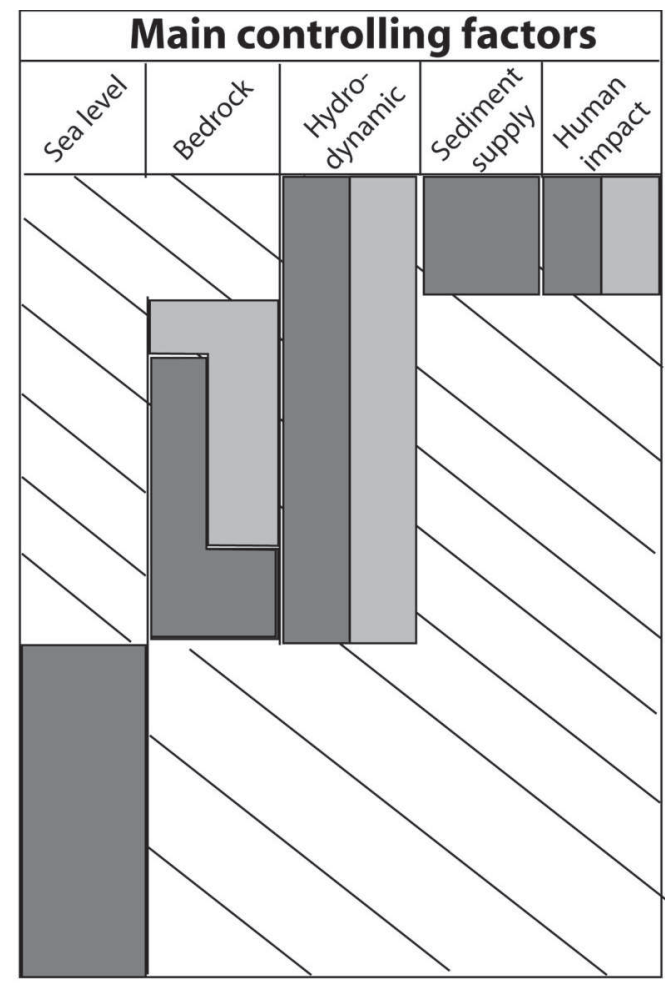

Slope front fill with a free seismic reflection configuration: Ue2

Lens with a progradational seismic reflection configuration: UT]

Valley-fill with a parallel seismic

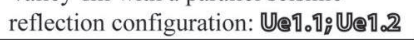

FIG. 14. - Synthetic stratigraphic logs showing the lateral variations of the Holocene-fill within the Marennes-Oléron Bay.

FIG. 14. - Logs synthétiques montrant les variations latérales du comblement sédimentaire holocène dans la baie de Marennes-Oléron. 
from the Gironde estuary, which is one of the most important sources of continental sediment supply within the Bay of Biscay (flux of suspended matter: $1.2-1.5 \times 10^{6} \mathrm{t}^{-\mathrm{yr}^{-1} \text { ) }}$ [Castaing and Jouanneau, 1987]. Actually, under certain oceanographic conditions, the Gironde plume is deviated clockwise at the end of the ebb and faces the two entrances of the MOB at the beginning of the flood [Froidefond et al., 1998], so that flood current can advect it into the MOB. This latter phenomenon can explain the relatively large amount of mud sedimentation in the NMOB and surrounding areas [Chaumillon et al., 2008b].

Mud-fill of the NMOB corresponds mainly to the mud drape (UT4), which has recorded an increase in mud supply since around 1000 years B.P., as observed elsewhere in Europe [Lesueur et al., 1996; Freitas et al., 2002; Leorri and Cearreta, 2004; Garcia-Garcia et al., 2005; Dinis et al., 2006]. Such major mud supply, which occurred during the middle age, may be related to soil erosion in response to extensive deforestation of Europe during this period [Lesueur et al., 1996; Freitas et al., 2002; Billeaud et al., 2005; Dinis et al., 2006]. Human influence on the MOB sediment-fill can be also inferred from the correlation of the position of oyster farms with sediment gain within intertidal areas during the last two centuries [Bertin and Chaumillon, 2006] and from the role of oyster farms, which create obstacles to currents favouring decantation [Sornin, 1981].

The fourth forcing parameters, namely eustasy, sediment supply, bedrock morphology and anthropogenic activities that have controlled the secular morphological evolutions and Holocene stratigraphy of the MOB have been also pointed out in many over semi-enclosed coastal environments. During the early Holocene, eustasy was the dominating element controlling the sedimentation of estuaries of Europe [Allen and Posamentier, 1994; Dias et al., 2000; Long et al., 2000; Freitas et al., 2002], Africa [Lang et al., 1995], North America [Knebel and Circé, 1988; Mallinson et al., 2005], South America [Gómez et al., 2005], Australia and New Zealand [Roy, 1994; Heap and Nichol, 1997]. During the middle Holocene, following the decrease in mean sea-level rise rate, sediment supply and climate changes became dominant in the control of sedimentation [Pendon et al., 1998; Moura et al., 2007]. Since then, anthropogenic activities, namely deforestation and increase in agriculture [Dabrio et al., 2000; Cronin and Vann, 2003; Vella et al., 2005; Bourrin et al., 2007; Dinis et al., 2006; Hubeny et al., 2008], land reclamation [Pontee et al., 1998], daming [Dias et al., 2000], mining [Jaffe et al., 2007], contributed decisively to the sediment balance in estuarine systems but also at a global scale [Hooke, 2000]. It can be concluded that the patterns observed in the MOB are not unique and reinforce the idea that estuarine-fills during Holocene were primarily controlled by eustasy and latter by autogenic factors and anthropogenic activities. In addition to these forcing parameters, the bedrock morphology plays a major role because the soft sedimentary cover is thin. Such control of antecedent topography was also evidence at the scale of the Bay of Biscay [Chaumillon et al., 2008b] and in similar coastal setting [Belknap and Kraft, 1985; Heap and Nichol, 1997; Lobo et al., 2003].

\section{CONCLUSION}

Analyses of bathymetric maps and very high-resolution seismic reflection profiles correlated with core samples have allowed us to make a synthesis of the morphological and stratigraphical evolutions of the Marennes-Oléron Bay. This study has provided a better knowledge concerning the sediment-fill of this tidal bay and related forcing parameters.

The Marennes-Oléron Bay sediment-fill is thin $(20 \mathrm{~m}$ at the maximum) and has displayed a positive sediment budget between 1824 and 2003. Two main depositional systems, namely, the southern and northern Marennes-Oléron Bay have been identified on the basis of both their morphological and stratigraphical evolutions.

The morphological evolution of the southern ebb dominated Marennes-Oléron Bay is characterised by sediment accretion on the tidal flats and the deepening of the main channels and the main part of its sediment-fill has been emplaced during the last centuries.

The northern flood-dominated Marennes-Oléron Bay is characterised by an increase in the elevation of both the tidal flats and channels bases, and five main stages have been distinguished in its sediment fill. The earliest filling stage (before $7500{ }^{14} \mathrm{C}$ yr B.P.) was controlled mainly by the last sea level variations whereas the remaining stages (from $7500-5000{ }^{14} \mathrm{C}$ yr B.P. to present-day) were successively controlled by autogenic factors, including hydrodynamic changes related to coastal evolutions, and by anthropogenic activities. In addition to these forcing parameters, the MOB represents an example of "rocky coast" estuary, where the sediment fill is very thin and discontinuous, and is characterised by a bedrock control at each phases of the sediment fill both in terms of preservation in topographic lows and in terms of control on hydrodynamics and related sediment input.

Acknowledgments. - The authors wish to thank the officer and crew of RV Côte de la Manche (CNRS/INSU), RV Côte d'Aquitaine (CNRS/INSU), and RV Les Deux Mouettes (Conseil Général de Charente Maritime). This study was supported by Conseil Général de Charente-Maritime, CNRS-INSU (Institut des Sciences de l'Univers). Bathymetric and coastline data sets have been supplied by the Service Hydrographique et Océanographie de la Marine (Convention E61/99, SHOM) and by Hydrographic Office of the Direction Départementale de la Charente-Maritime. The authors also wish to thank the Institut de Géographie National for making available topographic data sets (convention 9401/ IGN). Xavier Bertin is funded by the European Commission through a Marie Curie Intra-European Fellowship (contract IMMATIE MEIF-CT-2006-041171). Stéphane Recoura, Pascal Tiphaneau, Laure Paradis and Pascal Brunello are thanked for their help during fieldwork and artwork. 


\section{References}

Allard J., Chaumillon E., Poirier C., Sauriau P.-G. \& Weber O. (2008). - Evidence of former Holocene sea level in the Marennes-Oleron Bay (French Atlantic coast). - C. R. Geosciences, 340, 5, 306-314.

ALLEN J.R.L. (2000a). - Late Flandrian (Holocene) tidal palaeochannels, Gwent Levels (Severn Estuary), SW Britain: character, evolution and relation to shore. - Mar. Geol., 162, 2-4, 353-380.

AlLEN J.R.L. (2000b). - Morphodynamics of Holocene salt marshes: a review sketch from the Atlantic and southern North Sea coasts of Europe. - Quat. Sci. Rev., 19, 12, 1155-1231.

Allen G.P. \& Posamentier H.W. (1994). - Transgressive facies and sequence architecture in mixed tide and wave-dominated incised valleys: example from the Gironde estuary, France. In: R.W. DALRYMPle, R.J. Boyd \& B.A. Zaitlin, Eds, Incised valley systems: origin and sedimentary sequences. - SEPM (Soc. Sediment. Geol.) Spec. Publ., Tulsa, 51, 226-240.

Ashley G.M. \& Sheridan R.E. (1994). - Depositional model for valley fills on a passive continental margin. In: R.W. DALRYMPLE, R.J. BOYD \& B.A. ZAITLIN, Eds., Incised valley systems: origin and sedimentary sequences. - SEPM (Soc. Sediment. Geol.) Spec. Publ., Tulsa, 51, 285-301.

Bassoulet P., Le Hir P., Gouleau D. \& Robert S. (2000). - Sediment transport over an intertidal mudflat: field investigations and estimation of fluxes within the Baie de Marennes-Oleron (France). - Cont. Shelf Res., 20, 1635-1653.

BelKnAP D.F. \& KRAFT J.C. (1985). - Influence of antecedent geology on stratigraphic preservation potential and evolution of Delaware's barrier systems. - Mar. Geol., 63, 235-262.

BERTIN X. (2005). - Morphodynamique séculaire, architecture interne et modélisation d'un système baie/embouchure tidale: le pertuis de Maumusson et la baie de Marennes-Oléron. - Unpublished PhD Thesis, vol. 1, University of La Rochelle (France), 197 p.

Bertin X., Castelle B., Chaumillon E., Butel R. \& Quique R. (2008). Longshore transport estimation and inter-annual variability at a high energy dissipative beach: St Trojan beach, SW Oléron Island, France. - Cont. Shelf Res., 28, 10-11, 1316-1332.

Bertin X. \& Chaumillon E. (2005a). - Apports de la modélisation sur bathymétries historiques dans la compréhension des évolutions des bancs de sable estuariens. - C.R. Geosciences., 337, 15, 1375-1383.

Bertin X. \& Chaumillon E. (2005b). - New insights in shallow gas generation from very high resolution seismic and bathymetric surveys in the Marennes-Oleron Bay, France. - Mar. Geophys. Res., 26, 225-233.

Bertin X. \& Chaumillon E. (2006). - Evidences for oyster farming implications in increasing sedimentation rates in a macrotidal bay: the Marennes-Oléron Bay, France. - Cah. Biol. Mar., 47, 1, 19-22.

Bertin X., Chaumillon E., Sottolichio A. \& Pedreros R. (2005). - Tidal inlet response to sediment infilling of the associated bay and possible implications of human activities: The Marennes-Oléron Bay and Maumusson Inlet, France. - Cont. Shelf Res., 25, 1115-1131.

Bertin X., Chaumillon E., Weber N. \& Tesson M. (2004). - Morphological evolution and coupling with bedrock within a mixed energy tidal inlet: the Maumusson Inlet, France. - Mar. Geol., 204, 187-202.

Billeaud I., Chaumillon E. \& Weber O. (2005). - Correlation between VHR seismic profiles and cores evidences a major environmental change recorded in a macrotidal bay. - Geo-Mar. Lett., 25, $1-10$.

Boski T., Moura D., Veiga-Pires C., Camacho S., Duarte D., Scott D.B. \& Fernandes S.G. (2002). - Postglacial sea-level rise and sedimentary response in the Guadiana Estuary, Portugal/Spain border. - Sediment. Geol., 150, 1-2, 103-122.

Bourrin F., Monaco A., Aloisi J.-C., Sanchez-Cabeza J.A., Lofi J., Heussner S., Durrieu De Madron X., Jeanty G., Buscail R. \& SARGONi G. (2007). - Last millenia sedimentary record on a micro-tidal low-accumulation prodelta (Têt, NW Mediterranea). - Mar. Geol., 243, 1-4, 77-96.
Breton G., Cousin R., Huault M.-F., Lechevalier C. \& Lefebvre D. (1991). - Les sédiments quaternaires du quartier de l'hôtel de ville, au Havre: séquences marines pré-éémienne, éémienne et holocènes de l'estuaire de la Seine. - Bull. trim. Soc. géol. Normandie et Amis du Muséum du Havre, 78, 4, 15-63.

BRY C. \& Hoflack P. (2004). - Le bassin versant de la Charente. - Courrier de l'environnement de l'INRA, 52, 81-96.

Carbonel P., Dartevelle H., Evin J., Gruet Y., Laporte L., Marambat L., Tastet J.-P., Vella C. \& Weber O. (1998). - Évolution paléogéographique de l'estuaire de la Charente au cours de l'Holocène. In: L. LAPORTE, Ed., L'estuaire de la Charente de la Protohistoire au Moyen Âge. La Challonnière et Mortantambe (Charente-Maritime). - MSH, DAF 72, Paris, France, 15-25.

CARter R.M., Fulthorpe C.S. \& NAish T.R. (1998). - Sequence concepts at seismic and outcrop scale: the distinction between physical and conceptual stratigraphic surfaces. - Sed. Geol., 122, 1-4, 165-179.

Castaing P. \& Jouanneau J.M. (1987). - Les apports sédimentaires actuels d'origine continentale aux océans. - Bull. Lnst. Géol. Bassin d'Aquitaine (Bordeaux), 41, 53-65.

CEARreta A. (1993). - Paleoenvironmental interpetation of Holocene coastal sequences in the southern Bay of Biscay. - Geol. Rundsch., 82, 234-240.

Cearreta A. \& Murray J.W. (1996). - Holocene paleoenvironmental and relative sea-level changes in the Santoña Estuary, Spain. - J. Foramin. Res., 26, 289-299.

Chaumillon E., Bertin X., Falchetto H., Allard J., Weber N., Walker P., Pouvreau N. \& Wöppelmann G. (2008a). - Multi time-scale evolution of a wide estuary linear sandbank, the Longe de Boyard, on the French Atlantic coast. - Mar. Geol., 251, 3-4, 209-223.

Chaumillon E., Gillet H., Weber N. \& Tesson M. (2002). - Évolution temporelle et architecture interne d'un banc sableux estuarien : la Longe de Boyard (littoral Atlantique, France). - C. R. Geosciences, 334, 119-126.

Chaumillon E., Proust J.-N., Menier D. \& Weber N. (2008b). - Incised-valley morphologies and sedimentary-fills within the inner shelf of the Bay of Biscay (France): a synthesis. - J. Mar. Sys., 72, 383-396.

Chaumillon E., Tessier B. \& Reynaud J.-Y., Eds (2010). - French incised valleys and estuaries. - Bull. Soc. géol. Fr. 181, 2, 152 p.

Chaumillon E., Tessier B., Weber N., Tesson M. \& Bertin X. (2004). Buried sandbodies within present-day estuaries (Atlantic coast of France) revealed by very high resolution seismic surveys. Mar. Geol., 211, 189-214.

Chaumillon E. \& Weber N. (2006). - Spatial variability of modern incised valleys on the French Atlantic coast: comparison between the Charente (Pertuis d'Antioche) and the Lay-Sèvre (Pertuis Breton) incised-valleys. In: R.W. DALRYMPle, R.J. Boyd \& B.A. ZAITLIN, Eds., Incised valley systems: origin and sedimentary sequences. - SEPM (Soc. Sediment. Geol.) Spec. Publ., Tulsa, 51, 57-85.

Clavé B., Massé L., Carbonel P. \& TAstet J.-P. (2001). - Holocene coastal changes and infilling of the La Perroche marsh (French Atlantic coast). - Oceanolog. Acta, 24, 377-389.

CROnin T.M. \& VANn C.D. (2003). - The sedimentary record of climatic and anthropogenic influence on the Patuxent Estuary and Cheapeake Bay ecosystems. - Estuaries, 26, 2A, 196-209.

Dabrio C.J., Zazo C., Goy J.L., Sierro F.J., Borja F., Lario J., González J.A. \& Flores J.A. (2000). - Depositional history of estuarine infill during the last postglacial transgression (Gulf of Cadiz, southern Spain). - Mar. Geol., 162, 381-404.

DALRYMPLE R.W. \& ZAitlin B.A. (1994). - High-resolution sequence stratigraphy of a complex, incised valley succession, Cobequid Bay - Salmon River estuary, Bay of Fundy, Canada. - Sedimentology, 41, 1069-1091.

Decker L., Le Strat P., Karnay G., Bourgine B. \& Vairon J. (2001). Géométries et dynamique de remblayage de l'incision holocène dans le marais de Rochefort: modélisation géologique. BRGM/RP-51007-FR, BRGM, Orléans. 
Delanay C. \& Devoy R. (1995). - Evidence from sites in western Ireland of late Holocene changes in coastal environments. - Mar. Geol., 124, 273-287.

Devoy R.J.N. (1979). - Flandrian sea-level changes and vegetational history of the lower Thames Estuary. - Philos. Trans. R. Soc. London, Ser. B, 285, 355-407.

Dias J.M.A., Boski T., Rodrigues A. \& Magalhaes F. (2000). - Coast line evolution in Portugal since the last maximum until present-day synthesis. - Mar. Geol., 170, 177-186.

Dinis J.L., Henriques V., Freitas M.C., Andrade C. \& Costa P. (2006). Natural to anthropogenic forcing in the Holocene evolution of three coastal lagoons (Caldas da Rainha valley, western Portugal). - Quat. Int., 150, 41-51.

Freitas M.C., Andrade C. \& Cruces A. (2002). - The geological record of environmental changes in southwestern Portuguese coastal lagoons since the Late glacial. - Quat. Int., 93-94, 161-170.

Friedrichs C.T. \& Aubrey D.G. (1988). - Non-linear tidal distortion in shallow well-mixed estuaries: a synthesis. - Estuarine Coastal Shelf Sci., 27, 5, 521-545.

Froidefond J.M., Jegou A.M., Hermida J., Lazure P. \& Castaing P. (1998). - Variabilité du panache turbide de la Gironde par télédétection. Effets des facteurs climatiques. Variability of the Gironde turbid plume by remote sensing. Effects of climatic factors. - Oceanolog. Acta, 21, 191-207.

Gabet C. (1969). - Le marais de Brouage. - Bull. Soc. Géogr. de Rochefort, 2ème série, $2,6$.

Garcia-Garcia A., Garcia-Gil S. \& Vilas F. (2005). - Quaternary evolution of the Ria de Vigo, Spain. - Mar. Geol., 220, 1-4, 153-179.

Gómez E.A., Martínez D.E., Borel C.M., Guerstein G.R. \& Cusminsky G.C. (2005). - Submarine evidence of Holocene sea-level fluctuations in the Bahía Blanca estuary, Argentina. - J. South Amer. Earth Sci., 20, 139-155.

Gonzalez J.L., Jouanneau J.M., Dominik J. \& Boutier B. (1991). - Particulate $\mathrm{Cd}$ and $\mathrm{Hg}$ fluxes to the sediment in the Marennes-Oléron Bay: origin and evolution. - Environ. Technol., 12, 209-216.

Gouleau D., Jouanneau J.M., Weber O. \& Sauriau P.-G. (2000). - Shor and long-term sedimentation on Montportail-Brouage intertidal mudflat, Marennes-Oléron Bay (France). - Cont. Shelf Res., 20, 1513-1530.

HEAP A.D. \& Nichol S.L. (1997). - The influence of limited accommodation space on the stratigraphy of an incised-valley succession: Weiti river estuary, New Zealand. - Mar. Geol., 144, 229-252.

Higounet C. (1985). - Contribution à l'étude de la toponymie du défrichement: les "artigues" du Bordelais et du Bazardais. In: Paysages et villages neufs du Moyen Age. - Fédération Historique du Sud-Ouest, Bordeaux, 107-110.

Hubeny J.B., King J.W. \& Cantwell M. (2008). - Anthropogenic influences on estuarine sedimentation and ecology: examples from the varved sediments of the Pettaquamscutt River Estuary, Rhode Island. - J. Paleolimnol., 41, 297-314.

Hooke R.Leb. (2000). - On the history of humans as geomorphic agents. Geology, 28, 9, 843-846.

JAfFe B.E., Smith R.E. \& Foxgrover A.C. (2007). - Anthropogenic influence on sedimentation and intertidal mudflat change in San Pablo Bay, California, 1856-1983. - Estuarine Coastal Shelf Sci., 73, 1-2, 175-187

InMAN D.L. (1952). - Measures for describing size of sediments. - J. Sediment. Petrol., 19, 2, 125-145.

Knebel H.J. \& CirCÉ R.C. (1988). - Late Pleistocene drainage systems beneath Delaware Bay. - Mar. Geol., 78, 285-302.

LANG J., Anthony E.J. \& OYÉdÉ L.M. (1995). - Late Quaternary sediments in incised coastal valleys in Benin: a preliminary sequence-stratigraphic interpretation. - Quat. Int., 29-30, 31-39.

LAMBECK K. (1997). - Sea-level change along the French Atlantic and Channel coasts since the time of the Last Glacial Maximum. Palaeogeogr. Palaeoclimatol. Palaeoecol., 129, 1-22.

Lario J., Zazo C., Goy J.L., Dabrio C.J., Borja F., Silva P.G., Sierro F., GonZÁlez A., Soler V. \& Yll E. (2002). - Changes in sedimentation trends in SW Iberia Holocene estuaries (Spain). - Quat. Int., 93-94, 171-176.

LeOrRi E. \& CERreata A. (2004). - Holocene environmental development of the Bilbao estuary, northern Spain: sequence stratigraphy and foraminiferal interpretation. - Mar. Micropaleontol., 51, 1-2, 75-94.
Lesueur P., Tastet J.-P. \& Marambat L. (1996). - Shelf mud fields within historical times: examples from offshore the Gironde Estuary, France. - Cont. Shelf Res., 16, 1849-1870.

Lobo F.J., Dias J.M.A., González R., Hernández-Molina F.J., Morales J.A. \& DíAz Del Río V. (2003). - High resolution seismic stratigraphy of a narrow, bedrock-controlled estuary: the Guadiana Estuarine System, SW Iberia. - J. Sediment. Res., 73, 6 , 973-986.

Long A.J., Scaife R.G. \& Edwards R.J. (2000). - Stratigraphic architecture, relative sea-level, and models of estuary development in southern England: new data Southampton River. In: K. PyE \& J.R.L. Allen, Eds., Coastal and estuarine environments: sedimentology, geomorphology and geoarcheology. - Geol. Soc., London, Sp. Publ., 175, 253-279.

Mallinson D., Riggs S., Thieler E.R., Culver S., Farrell K., Foster D.S., Corbett D.R., Horton B. \& Wehmiller J.F. (2005). Late Neogene and Quaternary evolution of the northern Albemarle Embayment (mid-Atlantic continental margin, USA). Mar. Geol., 217, 97-117.

Mary G., Medus J. \& Delibrias G. (1975). - Le Quaternaire de la côte asturienne (Espagne). - Bull. AFEQ, 1, 13-23.

Migeon S., Weber O., Faugères J.-C. \& Saint-Paul J. (1999). - SCOPIX: A new X-ray imaging system for core analysis. - Geo-Mar Lett., 18, 251-255.

Moura D., Veiga-Pires C., Albardeiro L., Boski T., Rodrigues A.L. \& TARECO H. (2007). - Holocene sea level fluctuations and coastal evolution in the central Algarve (southern Portugal). - Mar. Geol., 237, 127-142.

PAwlowski A. (1998). - Géographie historique des côtes charentaises. Le Croix vif, Paris, 235 p.

Pendon J.G., Morales J.A., Borrego J., Jimenez I. \& Lopez M. (1998). Evolution of estuarine facies in a tidal channel environment, SW Spain: evidence for a change from tide-to wave-domination. Mar. Geol., 47, 1-4, 43-62.

Pitte J.R. (1983). - Histoire du paysage français, vol. II. - Tallandier, Paris, $203 \mathrm{p}$.

Pontee N.I., Tastet J.-P. \& Massé L. (1998). - Morpho-sedimentary evidence of Holocene coastal changes near the mouth of the Gironde and on the Medoc Peninsula, SW France. - Oceanol. Acta, 21, 2, 243-261.

Regnauld H., Jennings S., Delanay C. \& Lemasson L. (1996). - Holocene sea-level variations and geomorphological response: an example from northern Brittany (France). - Quat. Sci. Rev., 15, 781-787.

Roussel E.G., Sauvadet A.L., Allard J., Chaduteau C., Richard P., Cambon Bonavita M.A. \& Chaumillon E. (2009). - Active Archaeal methane cycling communities associated to gassy subsurface sediments of Marennes-Oléron Bay (France). - Geomicrobiol. J., 26, 1, $31-43$.

Roy P.S. (1994). - Holocene estuary evolution - stratigraphic studies from southeastern Australia. In: R.W. DALRYMPLE, R.J. Boyd \& B.A. ZAITLIN, Eds., Incised valley systems: origin and sedimentary sequences. - SEPM (Soc. Sediment. Geol.) Spec. Publ., Tulsa, 51, 241-263.

SÁNCHEZ GoÑ M.F. (1996). - Vegetation and sea level changes during the Holocene in the estuary of the Bidasoa. - Quat. Int., 7, 207-219.

S.H.O.M. (2003). - Annuaire des marées: Ports de France. - SHOM, Paris, $192 \mathrm{p}$.

SimPKIN P.G. \& DAVIS A. (1993). - For seismic profiling in very shallow water, a novel receiver. - Sea Technol., 9, 21- 28.

SORNIN J.-M. (1981). - Processus sédimentaires et biodéposition liés à différents modes de conchyliculture - baie de Cancale, anse de l'Aiguillon et bassin de Marennes-Oléron. - Unpublished PhD Thesis, University of Nantes (France), $188 \mathrm{p}$.

Spencer C.D., Plater A.J. \& Long A.J. (1998). - Rapid coastal change during the Mid- to Late Holocene: The record of barrier estuary sedimentation in the Romney Marsh region, Southeast England. - The Holocene, 8, 2, 143-163.

Tesson M. (1973). - Aspects dynamiques de la sédimentation dans la baie de Marennes-Oléron (France). - Unpublished PhD Thesis, University of Bordeaux (France) $\mathrm{n}^{\mathrm{O}} \mathbf{1 1 0 1}, 128 \mathrm{p}$

Thomas C.G., Spearman J.R. \& Turnbull M.J. (2002). - Historical change in the Mersey Estuary. - Cont. Shelf Res., 22, 1775-1794. 
Vail P.R., Audemard F., Bowman S.A., Eisner P.N. \& Perez-Cruz C. (1991). - The stratigraphic signatures of tectonic, eustasy and sedimentology - An overview. In: G. Einsele, W. Ricken \& A SeIlacher, Eds, Cycles and events in stratigraphy. - Springer-Verlag, Berlin, 617-659.

Van Der Wal D., Pye K. \& Neal A. (2002). - Long-term morphological change in the Ribble Estuary, northwest England. - Mar. Geol., 189, 3-4, 249-266.

Vella C., Fleury T.J., Raccasi G., Provansal M., Sabatier F. \& BourCIER M. (2005). - Evolution of the Rhône delta plain in the Holocene. - Mar. Geol., 222-223, 235-265.

VisSET L. (1988). - The Brière Marshlands: a palynological survey. - New Phytol., 110, 409-424.

Waller M.P., Long A.J., Long D. \& InNes J.B. (1999). - Patterns and processes in the development of coastal mire vegetation: Multi-site investigations from Walland Marsh, Southeast England. Quat. Sci. Rev., 18, 12, 1419-1444.
Weber N. (2004). - Morphologie, architecture des dépôts, évolution séculaire et millénaire du littoral charentais. Apports de la sismique réflexion combinée à des suivis bathymétriques et validés par des vibrocarottages. - Unpublished PhD, University of La Rochelle (France), 383 p.

Weber N., Chaumillon E., Tesson M. \& Garlan T. (2004a). - Architecture and morphology of the outer segment of a mixed tide and wave-dominated-incised valley, revealed by HR seismic reflection profiling: the paleo-Charente River, France. - Mar. Geol., 207, 17-38.

Weber N., Chaumillon E. \& Tesson M. (2004b). - Enregistrement de la dernière remontée du niveau marin dans l'architecture interne d'une vallée incisée : Le Pertuis Breton (Charente-Maritime). C.R. Geosciences, 336, 1273-1282.

ZAitlin B.A., DALRYMPle R.W. \& Boyd R. (1994). - The stratigraphic organisation of incised valley systems associated with relative sea-level change. In: R.W. DALRYMPle, R.J. BOYD \& B.A. ZAITLIN, Eds., Incised valley systems: origin and sedimentary sequences. - SEPM (Soc. Sediment. Geol.) Spec. Publ., Tulsa, 51 $45-60$ 